\title{
Cyber-Malpractice: Legal Exposure for Cybermedicine
}

\author{
Nicolas P. Terry
}

\section{INTRODUCTION}

This Article examines the content-related liability exposure of health care providers operating in cyberspace (cybermedicine). $\ddagger$ The Article maps real space theories 1 of liability such as professional negligence, misrepresentation and products liability to cybermedicine fact patterns.

This Article examines cybermedicine in contrast to the more widely discussed but narrower issue of telemedicine. ${ }^{2}$ The latter typically refers to technologies, primarily preconvergence telephony, satellite and video, used to patch geographical holes in health coverage. ${ }^{3}$ Thus, telemedicine is to medicine what distance learning is to education. ${ }^{4}$ Just as telemedicine technologies and goals have been more limited, so too have the legal issues been analyzed in a narrower regulatorys or

† Professor of Law, Saint Louis University. The author thanks Christopher Hoffman and Tonia Pfannenstiel (SLU Law 2000) for their diligent editorial assistance.

$\$$ Mention of a particular website in this Article is for illustrative or hypothetical purposes only. There is no suggestion and no suggestion should be taken that publishing a cybermedicine website itself constitutes actionable behavior or that sites mentioned herein have practiced cyber-malpractice or are liable on any other theory.

1 For the classic exposition on virtual space or cyberspace, see Mitchell Kapor \& John Perry Barlow, Across the Electronic Frontier (Electronic Frontier Foundation, Washington D.C.), July 10, 1990 (visited Apr. 20, 1999) <http://www.eff.org/pub/Publications/John_Perry_Barlow/ electronic_frontier.efs. Real space is used in this Article as the antonym to cyberspace, signifying the physical world.

2 See Daniel McCarthy, The Virtual Health Economy: Telemedicine and the Supply of Primary Care Physicians in Rural America, 21 AM. J.L. \& MED. 111, 112 (1995).

3 See id. at 112-16. For example, California has defined telemedicine as "[t]he practice of health care delivery, diagnosis, consultation, treatment, transfer of medical data, and education using interactive audio, video, or data communications. Neither a telephone conversation nor an electronic mail message between a health care practitioner and patient constitutes 'telemedicine' for purposes of this section." Cal. Bus. \& Prof. Code 2290.5(a)(1) (West 1999).

${ }^{4}$ Cf. Helen Leskovac, Distance Learning in Legal Education: Implications of Frame Relay Videoconferencing, 8 ALB. L.J. SCI. \& TECH. 305 (1998) (discussing distance learning as applied to legal education).

5 For examples of federal and state regulation of telemedicine, see CAL. HEALTH \& SAFETY CODE $\$ 1374.13$ (1999) (recognizing telemedicine as a legitimate means of receiving medical care by defining and regulating payment for telemedicine under Medi-Cal). See generally Christina M. Rackett, Telemedicine Today and Tomorrow: Why "Virtual" Privacy is Not Enough, 25 FordHAM URB. L.J. $167,183-90$ (1997) (discussing existing federal telemedicine legislation and proposing changes). $C f$. Metpath, Inc. v. Myers, 462 F. Supp. 1104, 1108-13 (N.D. Cal. 1978) (examining the constitutionality of a California regulatory statute authorizing the state to revoke or suspend the license of a clinical 
licensure 6 issues. 7 In contrast, cybermedicine is a broader concept. It encompasses not only the technology and legal issues of telemedicine, but also a far greater array of nontraditional and unique, technology-enabled interactions among health care providers and consumer-patients. 8 Cybermedicine includes marketing, relationship creation, advice, prescribing and selling drugs and devices, and as with all things in cyberspace, levels of interactivity as yet unknown.?

Part II summarizes the themes likely to pervade the discourse during the emergence of cybermedicine and the mapping of liability models (cybermalpractice) to World Wide Web (web) business models. To provide a firmer context, Part III briefly describes the presence of health care providers in cyberspace, and explains how some of their business models translate into cybermedicine. Then Part IV, V and VI identify three cybermedicine fact patterns that illustrate some or all of the themes identified earlier and that are likely to attract the initial forays into cyber-malpractice litigation. These fact patterns are: (1) web marketing by health care institutions; (2) web-based marketing and product support by pharmaceutical manufacturers; and (3) the proliferation of health-oriented advice sites. Part VII concludes with some brief observations about early attempts at managing cybermalpractice exposure.

\section{CYBERMEDICINE AND CYBER-MALPRACTICE: IDENTIFYING THE THEMES}

The use of a telephone by a physician to communicate a misdiagnosis to a patient does not automatically implicate telecommunications law. Equally, not every web or electronic mail (e-mail) ${ }^{10}$ contact injects cyberlaw concerns or issues into

laboratory that advertises to the public).

6 See Julie M. Keamey, Telemedicine: Ringing in a New Era of Health Care Delivery, 5 COMMLAW CONSPECTUS 289, 297-300 (1997) (discussing how telemedicine is making changes in licensure laws necessary because of interstate access issues). See, e.g., Katie Wood, Physiclans, Physician's Assistants, and Respiratory Care: Require Out-of-State Physicians Who Provide Patient Care in Georgia Via Telemedicine to Hold Georgia License, 14 GA. ST. U.L. REV. 238 (1997) (discussing Georgia's statute mandating licensing of physicians who enter the State for consultation via telemedicine).

7 See Christopher J. Caryl, Note, Malpractice and Other Legal Issues Preventing The Development of Telemedicine, 12 J.L. \& HEALTH 173, 179 (1998); Linda C. Fentiman, The Legal Questions From Tele-Medicine Five Major Issues Emerge, N.Y.L.J., Aug. 3, 1998, at 7; Phyllis Forrester Granade, Medical Malpractice Issues Related to the Use of Telemedicine-An Analysis of the Ways In Which Telecommunications Affects the Principles of Medical Malpractice, 73 N.D. L. REV. 65, 87 (1997) (discussing how not having a state license affects telemedicine and negligence liability); Christopher Guttman-McCabe, Telemedicine's Imperiled Future? Funding, Reimbursement, Licensing And Privacy Hurdles Face A Developing Technology, 14 J. CONTEMP. HEALTH L. \& POL'Y 161, 169, 171 (1997) (stating that physician licensing and differing state regulations inhibit telemedicine's growth). See generally Lynette A. Herscha, Is There a Doctor in the House? Licensing and Malpractice Issues Involved in Telemedicine, 2 B.U. J. SCI. \& TECH. L. 8 (1996) (discussing both licensure and malpractice standard-setting issues).

8 See generally Beverly J. Tyler, Cyberdoctors: The Virtual House-call-Actual Practice of Medicine on the Internet is Here, 31 IND. L. REV. 259 (1998) (discussing the Cyberdoctors website and how it demonstrates unique interactions between health care providers and patients).

9 See generally id. (discussing how the Cyberdoctors website uses the Internet to give medical advice and treatment).

10 See generally Beverly Kane \& Daniel Sands, Guidelines for the Clinical Use of Electronic Mall with Patients 5 J. AM. MED. INFORM. ASs'N. 104-11 (1998) (discussing the use of electronic mail (email) for communicating between physicians and patients); Kenneth W. Goodwin, ETHICS, CoMPUTINO, AND MEDicine (Cambridge Univ. Press 1998) (discussing the use of information technology in the provider-patient relationship). 
health care provider liability cases. Thus, not every cyberspace intrusion into traditional malpractice law will prompt radical reengineering of doctrinal stalwarts. However, certain themes will greet the early litigious stages of developing cybermedicine; themes that are rooted in web business models and emerging provider liability doctrine.

\section{A. THE EXPANSION OF PROVIDER LIABILITY}

This Article uses health care provider liability as a broad container for liability constructs that go beyond the paradigmatic malpractice case. ${ }^{11}$ Horizontally, the potential pool of defendants is expanded to include managed care organizations (MCOs) and, somewhat more controversially, pharmaceutical manufacturers. Vertically, a far broader array of fact patterns is entertained, contemplating a growing number of "information torts," 12 duties owed to nonpatients, product supply cases and access to care issues.

A somewhat cliched cyberspace observation nevertheless provides an appropriate starting point.13 Cybermedicine and hence cyber-malpractice will spill over traditional state or national borders. Thus, relatively provincial health care provider liability doctrinal structures will confront overlapping regulatory and liability systems, 14 intermingled with very difficult jurisdictional and extraterritoriality issues. 15

Even if one concentrates on domestic intrastate provider activities, the implications of cyberspace are far-reaching. In real space, we can usually distinguish between a pharmacy and a pharmaceutical manufacturer, between a physician group and an MCO, but such distinctions are not always so obvious when viewing a health care provider web page. Cyberspace technology and business models encourage high levels of integration. For example, surf to CyberPharmacy, ${ }^{16}$ apparently a $C y b e r D o c s^{17}$ sister site, and you will find the following encouragement:

11 The typical malpractice case involves a misdiagnosis or mistreatment of a patient by a doctor or hospital, implicating professional standards or informed consent.

12 I have been using this phrase for some time, see Nicolas P. Terry, Apologetic Tort Think: Autonomy and Information Torts, 38 ST. LoulS L.J. 189 (1993). I make no particular claim to its originality, see Henry H. Perritt, Jr., Tort Liability, the First Amendment, and Equal Access to Electronic Networks, 5 HARV. J.L. \& TECH. 65, 132 (1992) (using the phrase "information tort"). Also note that the phrase informational tort is often found in discussions of privacy law and theory.

13 As noted by David Johnson and David Post:

Cyberspace radically undermines the relationship between legally significant (online) phenomena and physical location. The rise of the global computer network is destroying the link between geographical location and: (1) the power of local governments to assert control over online behavior, (2) the effects of online behavior on individuals or things; (3) the legitimacy of a local sovereign's efforts to regulate global phenomena; and (4) the ability of physical location to give notice of which sets of rules apply. The Net thus radically subverts the system of rule-making based on borders between physical spaces, at least with respect to the claim that Cyberspace should naturally be governed by territorially defined rules.

Law and Borders-The Rise of Law in Cyberspace, 48 STAN. L. REv. 1367, 1370 (1996).

14 Viagra was officially available in the United Kingdom later than in the United States, but not as part of the socialized National Health Service package. See John Vidal, Desperately Seeking Viagra, THE GUARDIAN (London), Sept. 26, 1998, at 3, available in 1998 WL 18667701.

15 See Hope Viner Samborn, Small World, Big Questions, ABA J., Feb. 1999, at 78 (discussing the importance of establishing jurisdictional rules for the Internet to limit liability).

16 CyberPharmacy (visited Jan. 25, 1999) <http://www.cyberpharmacy.com>.

17 Cyberdocs (visited Apr. 16, 1999) <http://www.cyberdocs.com>. See infra note 183 and accompanying text. 
If you are seeking an online consultation with a physician for medical purposes, you may wish to check the CyberDocs Web site, where, depending on your geographic origin, you may be able to obtain an immediate (24hr/7day) or appointment-based keyboard and/or videoconferencing consultation with a live, board-certified physician. 18

Even discrete corporate entities appear integrated, due to the increasingly seamless transitions from one site to another along carefully chosen links. Factor in banner advertisements that may be placed by site participants, sponsors, crossmarketers or generic advertisers, and often it is difficult to fathom the nature of a visited site.

Further, courts will be faced with many new liability scenarios as the virtual world permits interactions simply not possible in real space. When such cases emerge, lawyers naturally engage in a process of mapping, or analogizing, from real space to these novel virtual space cases. 19 Thus, courts faced with health care provider liability actions premised on acts or omissions in cyberspace will be working from a strong, mature base of applicable and already expanding doctrine.

\section{B. AN EXPLOSION OF INFORMATION TORTS}

The most challenging real world health care provider liability actions involve information torts. These actions, such as informed consent and failure to warn, examine the relative information costs incurred by providers and patients rather than providers' insensitive interpersonal acts or substandard quality of care. ${ }^{20}$ In virtual space, all torts are information torts, ${ }^{21}$ and information has very different costs in cyberspace. 22 The costs of access to information are dramatically decreased because it is cheaper both to give advice and to receive it.23 As has been noted, "[t]he Web is the ultimate subversive medium. It allows people information they couldn't have got before. Doctors will just have to get used to patients with information."24

As the web dramatically increases the occasions for information provision and exchange, the result will be an explosion of health care provider actions that are concerned primarily with ex post facto judgment of the quality of information flow between provider and patient. Courts have thus far been hesitant to impose liability

18 CyberPharmacy (visited Jan. 25, 1999) <http://www.cyberpharmacy.com/content/ new_prescription.htm>. Of course, we already have some real space quasi-integrated services in, for example, retail ophthalmology and optometry. See, e.g., The LensCrafiers Eye Exam Advantage (visited Feb. 5, 1999) <http://www.lenscrafters.com/eyecare/buyglasses/lensexam.html> (stating that "Located next to every LensCrafters is an affiliated Licensed Doctor of Optometry.").

19 See, e.g., American Library Ass'n v. Pataki, 969 F. Supp. 160, 161 (S.D.N.Y. 1997) (stating that "[n]ot surprisingly, much of the legal analysis of Internet-related issues has focused on seeking a familiar analogy for the unfamiliar").

20 See, e.g., Johnson v. Kokemoor, 545 N.W.2d 495 (Wis. 1996) (alleging the physician failed to obtain the plaintiff's informed consent for surgery).

${ }^{21}$ I ignore what I view as "false" cybertorts, such as the real space battery of the plaintiff whom the defendant first met some months earlier in a cyberspace chat room. See Man Receives 40 Years in Killing That He Mentioned Online, N.Y. TIMES, Oct. 9, 1998, at A17 (visited Feb. 5, 1999) <http://www.nytimes.com/library/tech/98/10/biztech/articles/10confession.html>.

22 See Robert P. Merges, The End of Friction? Property Rights and Contract in the "Newtonian" World of On-Line Commerce, 12 BERKELEY TECH. L.J. 115, 116-17 (1997) (comparing conventional transaction costs to the costs generated through online transactions).

23 See id.

24 Hilary Bower, Open Wide and Say Ah, THE GUARDIAN (London), Jan. 12, 1999, at 14, available in LEXIS, News Library, GUARDN file (quoting Lynne McTaggart). 
in cases where inadequate information has not been directly linked to consent.2s Such positions are likely to come under increasing attack. These information tort cases will not be easy. As the web decreases many traditional information costs, it dramatically increases others. For example, the huge amount of information available increases sorting costs incurred by the consumer-patient. 26 Further, even leaving aside cases of fraud, electronic delivery complicates authenticating the source and assessing the reliability of information.27 Overall, the courts will be seriously challenged in creating mechanisms that properly allocate information cost risks between providers and patients.

Finally, it should not be forgotten that the web will dramatically decrease patient information costs, and later transaction costs, in discovering the existence of tortious provider behavior. Patients suffering adverse results will be more likely to discover a possible provider-related cause and initiate a process that will lead to litigation.

\section{The SACRIfICE OF IMMUNITIES TO BUSINESS MODELS}

Health care providers and drug manufacturers have discovered direct-toconsumer (DTC) or consumer-oriented marketing. ${ }^{28}$ Providers have used the web because it has become a major force in corporate marketing strategies. ${ }^{29}$ Yet, this embrace of mass media and interactive marketing has some interesting legal costs.

This theme may best be illustrated by two concrete examples that are expanded on below. First, the development of institutional provider (hospital or MCO) liability in the real world has been slowed by decades of decisions tending to favor an individual health care provider, typically physician, liability paradigm. ${ }^{30}$ In more recent years, some doctrinal rubble has been cleared. What has emerged is a picture of institutional provider liability that most often is triggered by institutional actions or expectation-creating marketing plans that deemphasize the individual physician paradigm in favor of an aggregated, tightly integrated and industrialized model. 31 This picture seems to map perfectly the business models chosen by health care institutions in cyberspace, 32

Second, drug manufacturers have employed the learned intermediary doctrine ${ }^{33}$

25 See, e.g., Arato v. Avedon, 858 P.2d 598 (Cal. 1993); Truman v. Thomas, 611 P.2d 902 (Cal. 1980); Morgan v. MacPhail, 704 A.2d 617 (Pa. 1997).

26 See Ira S. Nathenson, Internet Infoglut and Invisible Ink: Spamdexing Search Engines with Meta Tags, 12 HARV. J.L. \& TECH. 43, 90 (1998).

27 Docs Explore whether Online Medicine is Good Medicine, MED. INDUS. TODAY, Aug. 7, 1998, available in LEXIS, News Library, MEDTDY File.

28 Direct-to-consumer (DTC) advertising targets its advertising directly to the ultimate consumer, in this case, the patient. See Draft Guidance for the Industry, Consumer-Directed Broadcast Advertisements; Availability, 62 Fed. Reg. 43,171, 43,172 (1997).

29 See generally Kristen Green, Note, Marketing Health Care Products on the Internet: A Proposal for Updated Regulations, 24 AM. J.L. \& MED. 365 (1998) (discussing the extent of drug promotion on the Internet).

30 See Rebecca O'Neill, Surrogate Health Care Decisions for Adults in Illinois: Answers to the Legal Questions that Health Care Providers Face on a Daily Basis, 29 LOY. U. CHI. L.J. 411, 461 (1998).

31 See generally Kenneth S. Abraham \& Paul C. Weiler, Enterprise Liability and the Evolution of the American Health Care System, 108 HARV. L. REV. 381, 381 (1994) (describing the developing trend toward institutional liability rather than individual liability).

32 See discussion infra Part IV.

33 The learned intermediary doctrine holds that an adequate warning by a prescribing physician discharges a manufacturer's duty to warn. See Joseph G. Blute, Courts Struggle with the Learned 
to insulate themselves from certain product liability warning duties. ${ }^{34}$ That doctrine, ostensibly in place to fulfill a warning function, has permitted pharmaceutical manufacturers to transfer some drug-risk information costs to physicians and patients. 35 Yet, the entire doctrine is premised on an extremely low level of contact and interaction between manufacturer and patient. ${ }^{36}$ This is a premise that cannot withstand the empirical evidence of manufacturer web marketing. ${ }^{37}$ Both of these scenarios are examples of how institutions and manufacturers are increasing their real world vulnerability because of their virtual space activities. This is a theme or trend that is likely to flow beyond these immediate examples and initiate new forms of representational liability.

\section{The Recognition that Targeted Plaintiffs are Foreseeable}

Courts dealing with ex post facto liability models have tended to be negative toward liability theories with fact patterns involving injury-causing phenomena that exhibit low transaction costs. 38 This is particularly true in cases involving mass media exposure, 39 where liability is posited on the transmission of ideas rather than acts or omissions, or where the plaintiff relies on theories such as misrepresentation.40 Similar issues appear in the case of certain types of damages, such as emotional and economic, that tend to have ripple effects. 41 All cases seem to contemplate a relatively anonymous, untargeted and undifferentiated plaintiff pool.42

Such judicial hesitance is rooted in the sentiment that exposure to such forms of liability or damages should be closely controlled lest the courts become clogged.43 A frequent surrogate for this concern is the floodgates of litigation argument, 44 a statement of systemic concern perhaps best expressed by Justice Cardozo. He cautioned against exposing defendants to "liability in an indeterminate amount for an indeterminate time to an indeterminate class." 45 These sentiments also reflect a

Intermediary Rule Exceptions, PROD. LIAB. L. \& STRATEGY, May 1997, at 3, 3.

34 See, e.g., Ortho Pharmaceuticals Corp. v. Chapman, 388 N.E.2d 541, 549 (Ind. App. 1979) (finding the pharmaceutical manufacturer not liable under a strict tort liability theory).

35 Courts have permitted pharmaceutical manufacturers to externalize these costs by holding that a manufacturer's "liability turns on whether it sufficiently wamed [the prescribing physician] of a drug's dangerous propensities." Crisostomo v. Stanley, 857 F.2d 1146, 1152 (7th Cir. 1988).

36 See Barry R. Furrow, Enterprise Liability for Bad Outcomes from Drug Therapy, 44 DRAKE L. REV. 377, 387 (1996).

37 See discussion infra Part V.

38 See Joel Rothstein Wolfson, Electronic Mass Media Information Providers and Section 552 of the Restatement (Second) of Torts: The First Amendment Casts a Long Shadow, 29 RUTGERS L.J. 67, 118 (1997) (stating courts are hesitant to apply liability to "mass information providers," such as those on the Internet).

${ }^{39}$ See id. (discussing the liability of mass information providers for negligently creating or disseminating information).

40 See id. at 73.

41 See id. at 105.

42 See id.

43 See generally Stanley Sporkin, Reforming the Federal Judiciary, 46 SMU L. REV. 751, 757 (1992) (arguing federalizing crimes has resulted in an overloading of the federal courts).

${ }^{44}$ The "floodgates of litigation" concern is a combination of two problems: (1) subjecting courts to a socially expensive and haltingly burdensome amount of suits based on frivolous or nonmeritorious claims; and (2) subjecting possible defendants to suits not aimed at equitable recovery or compensation but at forcing defendants to settle to avoid expensive litigation costs. By opening the floodgates, there would be an undermining of the court system and a chilling of potentially socially beneficial activities by possible defendants in society.

45 Ultramares Corp. v. Touche, Niven \& Co., 174 N.E. 441,444 (1931). It is worth noting that, in 
concern for the system, i.e. costs or inefficiencies that could be incurred when losses that are spread out are harvested for reallocation. 46 Such pervasive themes or concerns frequently find doctrinal voice in judicial wavering as to finding a close connection between defendant's alleged negligence and the plaintiffs' injuries or some sense of a lack of moral blameworthiness. 47

Modern electronic commerce (e-commerce) and its enabling technologies break from the underlying precept on which defense victories in these cases are based. Obviously in cyberspace companies can have generalized mass marketing and announcements. Companies can literally reach an indeterminate class. It is already established as a tenet of cyberspace law that websites carry the potential for almost unlimited noncorporeal interaction. ${ }^{48}$ The product of such interaction and the gathering of user information allows a high level of profiling and item targeting, of sensitivity to the extremely narrow, personalized needs, wants, symptoms and conditions of the targeted person. 49

Thus, cybermedicine will suffer from what might be viewed as the penalty of

Ultramares, Justice Cardozo specifically distinguished between injuries caused by "physical force" and "the circulation of a thought or the release of the explosive power resident in words." Id. at 445.

46 Take a situation where damages (economic loss or emotional harm) are easily spread (has low transaction costs) and the damages are spread to an indeterminate number of random plaintiffs. It can be argued that it is more efficient to let the damages lie where they fell than to attempt to "harvest" them through the legal system so as to redistribute them, first, to a defendant and thereafter to the members of the defendant's insurance risk pool. This argument need not be viewed as correct; all that matters is that judges perceive this as a poor spreading scenario. Thus as Lord Denning said, It is not sensible to saddle losses on this scale on to one sole contractor. Very often such losses occur without anyone's fault. A mine may be flooded, or a power failure may occur by mischance as well as by negligence. Where it is only mischance, everyone grumbles but puts up with it. No one dreams of bringing an action for damages. So also when it occurs by negligence. The risk should be borne by the whole community rather than on one pair of shoulders, i.e. on one contractor who may, or may not, be insured against the risk. There is not much logic in this, but still it is the law.

SCM (United Kingdom) Ltd. v. W.J. Whitehall \& Son Ltd., I Q.B. 137 (1970), available in LEXIS, UK Library, ALLCAS File.

47 Whether a duty of care is owed in any particular instance is a question of law and "is the court's expression of the sum total of those considerations of policy which lead the law to say that the particular plaintiff is entitled to protection." Bigbee v. Pac. Telephone and Telegraph Co., 665 P.2d 947, 955 (1983). There are a number of such considerations:

the major ones are the foreseeability of harm to plaintiff, the degree of certainty that the plaintiff suffered injury, the closeness of the connection between the defendant's conduct and the injury suffered, the moral blame attached to the defendant's conduct, the policy of preventing future harm, the extent of the burden to the defendant and consequences to the community of imposing a duty to exercise care with resulting liability for breach, and the availability, cost, and prevalence of insurance for the risk involved.

Id.

48 See, e.g., Panavision Int'l, L.P. v. Toeppen, 141 F.3d 1316, 1316-24 (9th Cir. 1998); Mayo v. Memminger, 1998 U.S. Dist. LEXIS 13154 (N.D. Cal. 1998); GTE New Media Serv. v. Ameritech Corp., 21 F. Supp. 2d 27 (D.D.C. 1998); Conseco, Inc. v. Hickerson, 698 N.E.2d 816 (Ind. Ct. App. 1998).

49 See Jeri Clausing, Administration Seeks Input on Privacy Policy, N.Y. TIMES, Nov. 6, 1998 (visited Feb. 27, 1999) <http://www.nytimes.com/library/tech/98/1 l/cybet/articles/06privacy.html>; United States Department of Commerce, Electronic Commerce Task Force, Safe Harbor Principles (Feb. 28, 1999) <http://www.ita.doc.gov/ecom/menu.htm>; see also Jerry Kang, Information Privacy in Cyberspace Transactions, 50 STAN. L. REV. 1193 (1998) (discussing use of private data in cyberspace). See generally European Union Data Protection Directive (visited Feb. 25, 1999) <http://www2.echo.lu/ legal/en/dataprot/directiv/directiv.html> (outlining protection requirements with regard to processing and moving an individual's personal information). See, e.g., Craig Bicknell, For Sale: Your Tastes, Interests, WIRED NEwS, June 24, 1998, (visited Feb. 25, 1999) <http://www.wired.com/news/ print_version/business/story/13212.html> (discussing how companies are using individual tastes and interests to sell products). 
personalization. Interactivity brings targeting, and targeting bespeaks foreseeability. From the perspective of the health care provider's database, the potential plaintiffs are not undifferentiated, the drug-interactions are not unidentified and the symptoms or individuated risks are not unknown. In short, Cardozo's "indeterminate class" is no longer an anonymous undifferentiated one.

\section{HEALTH CARE PROVIDERS AND WEB-BASED BUSINESS MODELS}

The Internet (and, in its footsteps, the web) originated as a communications medium, ${ }^{50}$ mixing in scientific, educational and alternative cultures, to become a nascent community medium. Currently the web, fueled by rapidly evolving technological innovations, is in the process of evolving into a mass medium dominated by characteristics adapted from entertainment, marketing and retailing cultures and media. These tendencies will be confirmed and then accelerated by the growth of broadband access, 51 the adoption of Internet protocol52 as the universal transport for all data, including telephony and video, and the convergence of web and existing media.

Business models for the web53 have been difficult to define and implement, in part because enthusiastic early adopters of this content-rich environment have steadfastly refused to pay for pure data or information, often referred to as soft, webbased content. 54 In contrast, consumers have shown themselves increasingly willing to purchase some hard goods from the web. Established or bricks and mortar retailers 55 are engaged in a brutal struggle with web upstarts, 56 particularly in areas of easily shipped goods, such as books, videos and compact discs (CDs). Outside of web retailing of traditional hard goods (e.g., books or CDs) business models seem less focused. Entrepreneurial activity (including preparing the business for an initial public offering (IPO)) is frequently frantic, even schizophrenic, dominated more by branding, presence and cross-marketing than by real space business fundamentals such as revenue streams.57

Media companies generally seem to be concentrating on content leveraging and

50 See John Schwartz, Gore Deserves Internet Credit, Some Say: Online Experts Call Vice President's Efforts 'Instrumental' to Current System, WASH. POST, Mar. 21, 1999, at A4.

51 Broadband access permits several channels of information to be offered through a single medium. See Webopaedia (visited Mar. 22, 1999) <http://www.webopedia.com/TERM/b/ broadband transmission.htmls. Currently, broadband access is being touted by MediaOne as being capable of delivering "Superior Television Entertainment," "High Speed Intemet Access" and "Digital Telephone Service" over its cable lines. See MediaOne Products and Services (visited Mar. 28, 1999) <http://www.mediaone.com/products_services/default.htm>.

52 Internet protocol (IP) specifies both how data, to be sent from point $A$ to point $B$, is to be formatted and how point A and point B are to be assigned addresses. See Webopaedia (visited Mar. 22, 1999) <http://www.webopedia.com/TERM/I/IP.html>.

53 See generally Maureen O'Rourke, Fencing Cyberspace: Drawing Borders in a Virlual World, 82 MiNN. L. REV. 609, 624-30 (1998) (discussing how current laws should be applied to the Internet).

54 Data warehouses, such as Lexis@-Nexis $\bigotimes$, are not exceptions to the rule against charging for content as their markets were established prior to permitting web access. Notwithstanding, some information providers and some media companies are moving to per byte or per slice models. See, e.g., WestDoc (visited Jan. 25, 1999) <http://www.westdoc.com/forms/wdupdate.htm>; GoodNoise (visited Jan. 25, 1999) <http://www.goodnoise.com>.

55 See, e.g., Barnes and Noble (visited Jan. 25, 1999) <http://www.barnesandnoble.com>.

56 See, e.g., Music Boulevard (visited Jan. 25, 1999) <http:/www.musicblvd.com>; Amazon.com (visited Jan. 25, 1999) <http://www.amazon.com>.

57 See Jonathan Weber, Is It What You Sell or How That Matters More?, L.A. TIMES, July 28, 1997, at DI. 
brand management.58 Meanwhile, businesses that provide services that are not, or were not, consumer facing have embarked on ambitious web-based marketing plans and the adoption of the latest targeting and personalization technologies. 59 The recognized verity for web-based business models in thick markets is that the webpresence should be sticky; that is, a website should capture the loyalty of surfers so that they return or designate the site as their home page, the marketer's ideal.60 For a site to be sticky, it must comply with the contemporary web marketers' mantra of content, community and commerce.61 Clearly, health care providers are subscribing to this approach, looking first at content and communities to make their sites sticky, no doubt in preparation for more explicitly commercial activities.

In the first few years of its existence, the web's most innovative business model has been the portal.62 There are two portal models. The first and most obvious model, and that chased by major media and computer businesses, revolves around the provision by the portal site of a free service to web surfers, such as a search engine ${ }^{63}$ or e-mail. ${ }^{64}$ Such portals then sell their own products, third-party products and third-party advertising. 65 The second type of portal model has community elements, concentrating on particular web population subsets; they are known as vertical portals.66 Obviously this model has considerable relevance to established real space vertical markets such as law67 or health care. 68

Although drug companies and MCOs clearly seek a portal presence, they are also struggling with the targeting of their sites. Overall, provider websites fit within one of two broad models: those directed at other professional or commercial members of the vertical health market and those directed at consumer-patients. The web already has more than 1500 listings for medical equipment, 69 over 400 listings

58 See, e.g., MSNBC (visited Jan. 25, 1999) <http://www.msnbc.com>; see also Lisa Napoli, Magazine Publishers Search for Place Online, N.Y. TIMES, Oct. 30, 1998 (visited Feb. 19, 1999) <http://www.nytimes.com/library/tech/98/10/cyber/articles/30magazine.html>.

59 See, e.g., BMG Music Service (visited Feb. 16, 1999) <http://www.bmgmusicservice.com>; see also Stephanie Wilkinson, BMG Music Site is a Hit, PC WEEK ONLINE, Oct. 4, 1998, (visited Feb. 16, 1999) <http://www.zdnet.com/pcweek/stories/printme/0,4235,357087,00.html>.

60 See generally Bob Tedeschi, Caught in a Web of 'Sticky' Services, N.Y. TIMES, Oct. 20, 1998 (visited Mar. 28, 1999) <http://www.nytimes.com/library/tech/98/10/cyber/articles/20commerce.html> (discussing the efforts that companies make to retain web surfers).

61 See id.

62 See, e.g., Rajiv Chandraekan, Today's Hot Web Concept is 'Portals', WASH. POST, Oct. 11, 1998, at HOl (visited Feb. 23, 1999) <http://www.washingtonpost.com/wp-srv/washtech/daily/oct98/ portals $101198 . \mathrm{htm}>$.

63 See, e.g., Yahoo! (visited Jan. 25, 1999) <http://www.yahoo.com>.

64 See, e.g., Hotmail (visited Feb. 25, 1999) <http://www.hotmail.com>.

65 Third-party advertising typically appears as a banner on a portal site. These advertisements to use the latest euphemism are called sponsored links. For a review of possible advertising models, see Netmarketing, Business-10-Business Websites Top 200 (visited Feb. 25, 1999) <http://www.netb2b.com/ nm200> and Adresource (visited Feb. 25, 1999) <http://www.adresource.com/index.html $>$. Third parties are extremely interested in learning how effective these sponsored links are so they can justify the expense of them. See Craig Bicknell, Making Ads Hit Their Mark, WIREd NEws, Oct. 1998, (visited Feb. 25, 1999) <http://www.wired.com/news/print_version/business/story/15707.html> (discussing how Intemet sites can track users for advertising purposes). issues).

66 See, e.g., iVillage (visited Feb. 26, 1999) <http://www.ivillage.com> (focusing on women's

67 See, e.g., Counsel Connect (visited Feb. 26, 1999) <http://www.counsel.com>.

68 See, e.g., Physicians' Online® Network (visited Feb. 26, 1999) <http://www.po.com >.

69 See Yahoo! (visited Feb. 26, 1999) <http://dir.yahoo.com/Business_and_Economy/Companies/ Health/Medical_Equipment>. 
for medical suppliers, such as gloves, dental products, surgical instruments 70 and more than 4600 listings for medicine, generally specialties and subspecialties aimed at professionals. ${ }^{71}$ Of the sites that are more obviously aimed at consumer-patients, the web has over 1000 listings for U.S. hospitals and medical centers, 72 and more than seventy listings for managed care providers. ${ }^{73}$ Surfers will also find over 1100 listings for pharmaceuticals, including manufacturers, ${ }^{74}$ pharmacies and organizations seeking volunteers for clinical trials. ${ }^{75}$.

Somewhat more difficult to classify are the more than 5000 listings for individual diseases and conditions, ${ }^{76}$ and the more than 400 listings on specific drugs. 77 Take just the obvious example of Viagra sites listed by Yahoo!78 Of the sites, one is the official Viagra site 79 run by the manufacturer Pfizer, Inc. In addition, however, you will find the apparently commercial Viagra Resource Site 80 that offers Viagra information and links to what appear to be online doctors and pharmacies. The Yahoo! link also takes you to Viagra Talk, 81 which is hosted by a physician who is also a broadcaster and an author.

Taking into account the various cyber-malpractice themes that will lead the debate and the large number of provider liability business models, this Article now concentrates on three emergent tendencies in cybermedicine to illustrate these liability themes. As noted earlier, these trends are web-based marketing by health care institutions, particularly hospitals and MCOs, web-based marketing and product support by pharmaceutical manufacturers, and the proliferation of health-oriented advice sites. Throughout this Article, the concentration is on relative threshold issues such as whether a plaintiffs claim would survive a motion to dismiss or summary judgment, leaving more granular issues such as the content of the duty of care for later analysis.

\section{WEB-MARKETING AND INSTITUTIONAL LIABILITY}

In recent years, a much clearer picture of real space institutional provider liability in malpractice cases has emerged.82 However, some areas of the picture still

\footnotetext{
70 See Yahoo! (visited Feb. 26, 1999) <http://dir.yahoo.com/Business_and_Economy/Companies/ Health/Medical_Supplies>.

71 See Yahoo! (visited Feb. 26, 1999) <http://www.yahoo.com/Health/Medicine>.

72 See Yahoo! (visited Feb. 26, 1999) <http://dir.yahoo.com/Business_and_Economy/Companies/ Health/Hospitals_and_Medical_Centers>.

73 See Yahoo! (visited Feb. 26, 1999) <http://dir.yahoo.com/Business_and_Economy/Companies/ Financial_Services/Insurance/Health/Managed_Care_Providers>.

74 For a listing of the web addresses of the leading drug manufacturers, see Pharmaceutical Companies on the World Wide Web (visited Feb. 26, 1999) <http://members.aol.com/pharminf/ ph_listl.html>.

75 See Yahoo! (visited Feb. 26, 1999) <http://dir.yahoo.com/Business_and_Economy/Companies/ Health/Phamaceuticals $>$.

76 See Yahoo! (visited Feb. 26, 1999) <http://dir.yahoo.com/Health/Diseases_and_Conditions>.

77 See Yahoo! (visited Feb. 26, 1999) <http://dir.yahoo.com/Health/Pharmacy/ Drugs_and_Medications/Specific_Drugs_and_Medications $>$.

${ }_{78}$ See Yahoo! (visited Feb. 26, 1999) <http://dir.yahoo.com/Health/Pharmacy/ Drugs_and_Medications/Specific_Drugs_and_Medications/Viagra_Sildenafil>.

$\overline{79}$ See Viagra (visited Feb. 26,1999$)<$ http://www.viagra.com>.

${ }^{80}$ See Viagra Resource Site (visited Feb. 26, 1999) <http://www.globalite.com/viagra.html>.

81 See Viagra Talk (visited Jan. 16, 1999) <http://www.bigv.com>.

82 See, e.g., Barry R. Furrow, Managed Care Organizations and Patient Injury: Rethinking Liability, 31 GA. L. REV. 419, 509 (1997) (discussing developments in enterprise liability); Clark C. Havinghurst, Making Health Plans Accountable for the Quality of Care, 31 GA. L. REV. 587, 647
} 
remain opaque. For example, questions remain as to the extent of common law ${ }^{83}$ or statutory 84 liability of MCOs with regard to the decision to approve or disapprove of particular medical treatments. In addition, the exact interface between institutional MCO liability and the Employee Retirement Income Security Act (ERISA) remains an area of difficulty.85 However, what has become clear is that an institution's marketing now plays a significant role in determining the extent of its indirect institutional tort liability. 86

There are an almost infinite number of web models available to shape an institutional health care providers' web presence. Extant examples include simple marketing and informational sites, ${ }^{87}$ health maintenance organizations (HMOs) exhibiting considerable levels of integration, 88 fully integrated managed care systems ${ }^{89}$ and vertical portals serving multiple constituencies.90 Clearly health care institutions have discovered DTC or consumer-oriented marketing, which will have serious liability exposure implications.

As is well known, the two traditional routes for imposing legal responsibility on an institutional provider are indirect or vicarious liability and direct or corporate liability.91 The latter is relatively uncontroversial in cases involving facilities,

(1997) (same); William M. Sage \& James M. Jorling, A World That Won't Stand Still: Enterprise Liability By Private Contract, 43 DePAul L. REv. 1007, 1043 (1994) (same); William M. Sage et al., Enterprise Liability For Medical Malpractice and Health Care Quality Improvement, 20 AM. J.L. \& MED. 1, 28 (1994) (same); see also Kenneth S. Abraham \& Paul C. Weiler, Enterprise Medical Liability and the Evolution of the American Health Care System, 108 HARV. L. REv. 381 (1994) (discussing the history of enterprise liability).

83 See, e.g., Grijalva v. Shalala, 152 F.3d 1115, 1117 (9th Cir. 1998) (holding that a Health Maintenance Organization's (HMO) denial of medical services created a federal cause of action); Wash. Physicians Serv. v. Gregoire, 147 F.3d 1039, $1045-46$ (9th Cir. 1998) (holding that The Employee Retirement Income Security Act (ERISA) does not preempt Washington's Alternative Provider Statute, which requires HMOs to cover several alternative medical treatment options); Andrews-Clarke v. Travelers Ins. Co., 984 F. Supp. 49, 54-55 (D. Mass. 1997) (holding that the insurance beneficiaries' claims were preempted by ERISA, which does not authorize recovery for common law wrongful death or personal injury caused by an improper refusal to authorize treatment); Robert Pear, Hands Tied, Judges Rule Law That Limits H.M.O. Liability, N.Y. TIMES, July 11, 1998, at A1.

84 See Tex. Civ. PRAC. \& REM. CODE \$§ 88.001-.003 (West 1997); D.C. CODE ANN. § $35-4526$ (1998). See genterally Carol Marie Cropper, In Texas, a Laboratory Test on the Effects of Suing H.M.O.s, N.Y. TIMES, Sept. 13, 1998, at C3 (discussing the numbers of lawsuits filed under a new Texas law that allows suing HMOs for malpractice and discussing potential ERISA defenses); David Schultz \& Tracey Galinson, Suits Against Managed Care Providers May Elude ERISA, NAT'L L.J., July 6, 1998, at B9, available in WL 7/6/98 Nat'I L.J. B9, (col. 2) (discussing ERISA's preemptive effects on medical malpractice lawsuits for wrongful denial of benefits).

85 See Moscovitch v. Physicians Health Services, 24 F. Supp. 2d 74, 80 (D. Conn 1998) (holding that ERISA did not completely preempt HMO participant's claims against the medical plan administrator); see also HMOs Can Be Sued in Connecticut, NAT'L L.J., Nov. 9, 1998, at A8, available in WL 11/9/98 Nat'l L.J. A8, (col. 1) (discussing Moscovitch and noting that an HMO may be liable for quality of care rather than denial of benefits).

86 See Boyd v. Albert Einstein Med. Ctr., 547 A.2d 1229 (Pa. Super. Ct. 1988) (holding that because HMO advertising caused the consumer to reasonably conclude that the physicians were HMO employees and caused consumers to select the HMO rather than the individual physician, the HMO could be held liable for the physician's negligence).

87 See Catholic Health Care West (visited Feb. 2, 1999) <http://www.chw.edu>.

88 See Kaiser Permanente Welcome (visited Feb. 2, 1999) <http://www.scl.ncal.kaiperm.org>.

89 See Welcome to Allina Health System (visited Jan. 26, 1999) <http://www.allina.com>. Cf. Community Hospital of Los Gatos (visited Jan. 26, 1999) <http://www.tenethealth.com/LosGatos> (referring to "our physicians" but only providing a physician referral service).

90 See Oxford Health Plans (visited Feb. 2, 1999) <http://www.oxhp.com>.

91 For a discussion of both vicarious and corporate liability for Managed Care Organizations (MCOs) and hospitals, see BARRY R. FURROW et al., HEALTH LAW 289-331 (Hombook Series, West 1995). 
equipment and maintenance of premises.92 However, the law is considerably less settled in cases involving core medical care services. ${ }^{93}$ Questions remain both about the reach of duty issues, such as its applicability to informed consent and to certain types of plaintiffs, ${ }^{94}$ and there is uncertainty about the liability trigger, whether it is review or supervision. 95

Today, the vicarious liability game is played out using a number of theories: case-by-case ostensible agency;96 agency-based on the right to control rather than actual control;97 agency by estoppel;98 apparent authority/agency;99 and nondelegable duty. 100 Law professors, unlike their students, arguably would never have tired of this messy arsenal of case-by-case reallocation tools. However, the courts seem to have had enough. A growing number of courts have moved toward an enterprise liability model that, given its conceptual underpinnings, utilizes a wideranging representational theory, a theory driven by providers' chosen business models.

Kashishian v. Port 101 was the breakthrough case. In Kashishian, the plaintiff argued that a hospital should be liable for the alleged negligence of a nonemployee cardiologist. ${ }^{102}$ The plaintiff's doctrinal route was apparent agency, which, as has been noted, is frequently used as a basis for institutional liability. 103 Kashishian expanded liability beyond narrow fact patterns, such as emergency rooms or radiology departments and stressed the marketing endeavors of the institutional defendant as key, stating:

Cases and commentaries on the doctrine invariably point to the recog-

\footnotetext{
92 See id. at 297-99, 301-05 (discussing corporate duties to properly select and retain medical staff and maintain premises).

93 Core medical services can be defined as those services that compose the basic services offered by a hospital such as obstetrics, cardiology and radiology. See Cheryl Clark, Fallbrook Hospiral Deal Spurs Recall Effort, SAN DIEGo UNION-TRIBUNE, Sept. 9, 1997, at B4.

94 For a discussion of corporate negligence and a hospital's duty to protect third parties, such as nonpatients, see Pedroza v. Bryant, 677 P.2d 166 (Wash. 1994). In Pedroza, the court refused to impose corporate liability on a hospital that granted hospital privileges to a nonemployee physician who allegedly harmed a patient in his private office, off the hospital premises. See id. at 172.

95 See Darling v. Charleston Community Mem'l Hosp., 211 N.E.2d 253 (Ill. 1965) (representing the emergence of corporate negligence and the duty to protect patients from medical staff negligence).

96 See Schlotfeldt v. Charter Hosp., 910 P.2d 271 (Nev. 1996) (representing the general rule in vicarious liability doctrine that a doctor-hospital agency relationship must exist for the doctor's acts to attribute liability to the hospital, and that the existence of the relationship, even an ostensible agency relationship, is a question of fact for a jury); BARRY R. FURROW et al., HeALTH LAw: CASES, Materials AND Problems 240 (3d ed. West 1997).

97 See Berel v. HCA Health Serv. of Texas, Inc., 881 S.W.2d 21, 21 (Tex. Ct. App. 1994) (stating the control test for vicarious corporate liability as "It is the right of control, not actual control, that gives rise to a duty to see that the independent contractor performs his work in a safe manner").

98 See Sword v. NKC Hosp., Inc., 661 N.E.2d 10 (Ind. Ct. App. 1996) (exemplifying the ostensible agency test for vicarious corporate liability, but also discussing agency by estoppel as predicated on the RESTATEMENT (SECOND) OF AGENCY $\S 267$ ).

99 See Jackson v. Power, 743 P.2d 1376 (Alaska 1987) (demonstrating the nondelegable duty rule from agency law as applied to corporate negligence cases); Sword, 661 N.E.2d at 10; Francisco v. Hartford Gynecological Ctr., Inc., No. CV92-0513841 S, 1994 Conn. Super. LEXIS 521 (Mar. 1, 1994); Houghland v. Grant, 891 P.2d 563 (1995).

100 See Jackson, 743 P.2d 1376; Beeck v. Tucson General Hosp., 500 P.2d 1153 (Ariz. 1972) (discussing the inherent function test for vicarious corporate liability and the doctrine of nondelegable duty).

101481 N.W.2d 277 (Wis. 1992).

102 See id. at 278.

103 See supra note 99 (cases representing apparent agency as a basis for institutional liability).
} 
nition that hospitals increasingly hold themselves out to the public in expensive advertising campaigns as offering and rendering quality health care services. One need only pick up a daily newspaper to see full and half page advertisements extolling the medical virtues of an individual hospital and the quality health care that the hospital is prepared to deliver in any number of medical areas. Modern hospitals have spent billions of dollars marketing themselves, nurturing the image with the consuming public that they are full-care modern health facilities. All of these expenditures have but one purpose: to persuade those in need of medical services to obtain those services at a specific hospital. In essence, hospitals have become big business, competing with each other for health care dollars. As the role of the modern hospital has evolved, and as the image of the modern hospital has evolved (much of it self-induced), so too has the law with respect to the hospital's responsibility and liability towards those it successfully beckons. Hospitals not only employ physicians, surgeons, nurses, and other health care workers, they also appoint physicians and surgeons to their hospital staffs as independent contractors. What is the responsibility of hospitals when these independent contractors render negligent health care? Can they escape liability for the rendering of negligent health care in all instances simply because the person rendering the care was an independent contractor, regardless of how hospitals held themselves out to the consuming public, regardless of how the doctor rendering the health care held himself or herself out to the consuming public, and regardless of the perception created in the mind of the consuming public? We think not. 104

In Sword v. NKC Hospitals, Inc., 105 the plaintiffs sought to use apparent agency theory to hold an institution liable for the alleged negligence of a nonemployee anesthesiologist. 106 The court refused to enter the morass of traditional apparent agency case law or navigate the intricacies of either ostensible agency 107 or agency by estoppel. 108 Instead, it showed a preference for a sui generis theory, as follows:

For a hospital to be held liable for the negligence of a health care professional under the doctrine of apparent agency, a plaintiff must show that the hospital acted or communicated directly or indirectly to a patient in such a manner that would lead a reasonable person to conclude that the health care professional who was alleged to be

104 Kashishian, 481 N.W.2d at 282 (footnote omitted).

105661 N.E.2d 10 (Ind. Ct. App. 1996).

106 See id. at 12.

107 See id.

One who employs an independent contractor to perform services for another which are accepted in the reasonable belief that the services are being rendered for the employer or by his servants, is subject to liability for physical harm caused by the negligence of the contractor in supplying such services to the same extent as though the employer were supplying them himself or by his servants.

RESTATEMENT (SECOND) OF TORTS $\$ 429$ (1965).

108 See Sword, 661 N.E.2d 10.

One who represents that another is his servant or other agent and thereby causes a third person justifiably to rely upon the care or skill of such apparent agent is subject to liability to the third person for harm caused by the lack of care or skill of the one appearing to be a servant or other agent as if he were such.

RESTATEMENT (SECOND) OF AGENCY $§ 267$ (1958). 
negligent was an employee or agent of the hospital, and that the plaintiff justifiably acted in reliance upon the conduct of the hospital, consistent with ordinary care and prudence. 109

Applying that test, the Sword court reversed the defendant's summary judgment holding in favor of the defendant, because of evidence drawn exclusively from the defendant's external marketing, including brochures and comparative advertising. 110

Finally, in Petrovich v. Share Health Plan of Illinois, Inc., III the plaintiff sought to hold an HMO112 liable for the alleged negligence of two participating independent contractor physicians, a primary care doctor and an ear, nose and throat specialist.113 The court found evidence that suggested elements of traditional control over the physicians by the HMO, including monitoring for substandard care and capitation.114 Crucially, however, the court referenced the HMO's member handbook statement which provides that the HMO would provide "all your healthcare needs" and "comprehensive quality services." 115

Of course, many jurisdictions continue to use a previous generation liability model, such as the right to control, as the trigger for institutional liability. 116 Others favor a position of institutional liability without resort to representational theories. 117 However, notwithstanding a particular state's doctrinal preference, the reality is that a provider's web presence will frequently deliver a message at odds with that crafted by its liability exposure managers, increasing its real world vulnerability. Liabilityattracting marketing does not have to be web-based. Yet, websites, because of the

109 Sword, 661 N.E.2d at 15 (footnote omitted).

110 See id. at 15-16.

111696 N.E.2d 356 (IIl. App. 1998).

112 The HMO at issue was an independent practice association (IPA) model, where the HMO contracts with independent medical groups to provide patient services, as opposed to a staff model, where the HMO employs physicians directly to provide services. See id. at 359 .

113 See id. at 358.

114 See id. at 362.

115 See id. at 359, 363. See also Sorrells v. Egleston, 474 S.E.2d 60, 61-63 (Ga. Ct. App. 1998) (reversing the trial court's grant of summary judgment for the hospital because there was a genuinc question of material fact regarding whether the informed consent forms explicitly notified the parcnts that the physicians were not hospital employees); Gilbert v. Sycamore Mun. Hosp., 622 N.E.2d 788, 794-96 (III. 1993) (reversing summary judgment for the hospital because a genuine issue of material fact existed as to whether the physician was an apparent agent of the hospital, where the hospital's treatment consent form stated that he would be treated "by physicians and employees of the hospital"); Gragg v. Calandra, 696 N.E.2d 1282, 1287-88 (Ill. App. 1998) (holding that a hospital can be held liable for the negligent acts of a physician providing care at the hospital, even when an agent commits an-intentional tort while furthering the business of the principal); Dahan v. UHS of Bethesda, Inc., 692 N.E.2d 1303, 1307 (Ill. App. 1998) (finding the hospital liable for the acts of its agent physician where the patient did not know the physician was an independent contractor).

116 See, e.g., Berel v. HCA Health Services of Texas, Inc., 881 S.W.2d 21 (Tex. Ct. App. 1994) (holding that a hospital's ability to override an independent physician's orders through utilization review procedures raises a genuine issue of material fact regarding control). But cf. Chase $v$. Independent Practice Ass'n, Inc., 583 N.E.2d 251 (Mass. App. Ct. 1991) (holding that the IPA's utilization review procedures and cost-containment clauses did not raise a genuine issue of fact regarding control because the IPA did not have the right to hire or fire independent physicians, nor could the IPA alter the physician's salaries, work schedules, or terms of employment).

117 Although no court has explicitly adopted enterprise liability for health care providers, some courts have done so implicitly. See, e.g., Alden v. Providence Hosp., 382 F.2d 163, 166 (D.C. Cir. 1967) (noting that even though an independent physician may be in charge of the patient, the hospital remains liable for the negligent acts of its employee physicians, nurses, interns, attendants or laboratory staff). But see, e.g., Jackson v. Power, 743 P.2d 1376 (Alaska 1987) (rejecting enterprise liability, and instead adopting apparent authority as the test for vicarious liability). 
low marginal cost of increasing the number of pages, ${ }^{118}$ or perhaps because they are rendered sticky by content, tend to encourage far more elaborate and integrated messages about the health services offered. Structural implications swiftly follow. Provider web activity, much like other corporate marketing activity, will tend to confirm the movement away from individual health provider liability, such as physician liability, and secondary liability models, such as institutional liability based on respondeat superior, to industrialized or institutional medicine's corporate or enterprise liability.

\section{DRUG MANUFACTURERS AND DIRECT MARKETING}

The pharmaceutical industry has zealously adopted DTC advertising. 119 The impetus came, of course, when the Food and Drug Administration (FDA) relaxed 120 many of its marketing controls. 121 . While DTC legal literature is already quite mature, it has, with a few exceptions, ${ }^{122}$ concentrated on marketing through

118 Website advertising is less costly to produce than traditional media. See O'Rourke, supra note 53 , at 629 .

119 See Steven W. Kopp \& Mary Jane Sheffet, The Effect of Direct-to-Consumer Advertising of Prescription Drugs on Retail Gross Margins: Empirical Evidence and Public Policy Implications, $16 \mathrm{~J}$. PUB. POL'Y \& MARKETING 270 (1997), available in LEXIS, Market Library, JPP\&M file; The Name Game, MED. AD. NEwS, Aug. 1, 1998, at 3, available in 1998 WL 10479236; New Consumer Campaigns, MED. AD. NEws, Aug. 1, 1998, at 12, available in 1998 WL 10479241; The Preapproval Edge; Pharmaceutical Firms Turn to Preapproval Advertising to Gain Market Edge, MED. AD. NEWS, May 1, 1998, at 1, available in 1998 WL 10478970; Warren R. Ross, How DTC Broke Advertising's Berlin Wall: Direct-1o-Consumer Advertising of Pharmaceutical Products, MED. MARKETING \& MEDIA, June 1998, at 76; see also FDA Puts Stop to Schering-Plough's TV Antihistamine Ads, MED. INDUS. TODAY, Aug. 25, 1997, available in LEXIS, News Library, MEDTDY file the Food and Drug Administration (FDA) has expressed its concerns with DTC prescription drug advertising because the Schering-Plough Corp. did not properly explain the side effects of its drug); Lilly's Drug Ad Guidelines Praised by State Medical Group, MED. INDUS. TODAY, Mar, 30, 1998, available in LEXIS, News Library, MEDTDY file (Eli Lilly \& Co. became one of the first pharmaceutical companies to develop guidelines to regulate how it advertises its prescription drugs).

120 See Direct-to-Consumer Promotion, 61 Fed. Reg. 24,314 (1996); Draft Guidance for Industry; Consumer-Directed Broadcast Advertisements; Availability, 62 Fed. Reg. 43,171 (1997). For the FDA's own summary, see the PowerPoint slide show (visited Feb. 2, 1999) <http://www.fda.gov/cder/ ddmac/DIAANNUAL.DTC.698.PPT>.

121 See generally Milton Liebman, FDA Takes the Mystery Out of TV Ads, MED. MaRkETING \& MEDIA, Sept. 1997, at 34, 34 (noting that the FDA issued guidelines setting out a practical approach for advertising prescription drugs, requiring a statement disclosing all major risks associated with the drug); Marlene K. Tandy, Regulatory Affairs Perspective; FDA Attempt To Regulate Public Comments Carried On The Internet Has Certain Limits; Commercial Speech On Devices Is OK, BIOMEDICAL MARKET NEWSL., Jan. 25, 1997, available in LEXIS, Market Library, IACNWS File (arguing that the FDA should be extraordinarily cautious before regulating medical device promotion and advertising because of free speech concems and suggesting instead that the FDA remain within the boundaries of the statutory authority it has pursuant to the federal Food, Drug \& Cosmetic Act); Tamar Nordenberg, Direct To You: TV Drug Ads That Make Sense; Includes Related Articles on Pharmaceutical Products Advertising on the Internet and Ad Regulations, FDA CONSUMER, Jan. 11, 1998, at 7, 7 (explaining that DTC advertising does have beneficial purposes, however, it may mislead consumers because they do not provide consumers with a complete picture of the drug).

122 See generally Peter S. Reichertz, Understanding Government Regulation of the Marketing and Advertising of Medical Devices, Drugs, and Biologics: The Challenges of the Internet, 52 FOOD \& DRUG L.J. 303 (1997) (reviewing FDA progress in determining how pharmaceutical companies can market medical devices, drugs and biologics on the Internet); Marc J. Scheineson, Legal Overview of Likely FDA Regulation of Internet Promotion, 51 FOOD \& DRUG L.J. 697 (1996) (considering FDA and Federal Trade Commission (FTC) regulation of Intermet-based advertising, including use of interactive graphics to manipulate and convey drug information); David W. Opderbeck, How Should FDA Regulate Prescription Drug Promotion on the Internet?, 53 FOOD \& DRUG L.J. 47 (1998) (addressing the history, culture, technology and popular uses of the Internet, using model regulations presented at a 1996 FDA 
traditional media.123 Meanwhile, attention in cyberspace, particularly that of the popular press, has concentrated on shifts in pharmaceutical distribution, particularly that of sildenafil citrate, or Viagra. 124 Such direct sales implicate potential regulatory and liability exposure of retailers, physicians and pharmacies;125 trends that will continue as online pharmacies proliferate. 126

Direct sales issues aside, cybermedicine, specifically DTC on the web, suggests some far more radical shifts in pharmaceutical manufacturer exposure.127 DTC marketing has become common on television and in magazines. However, the purpose of broadcast and print advertisements is to promote brand awareness. 128 These advertisements remain relatively shallow and light in content, and exist primarily as pointers to health care professionals. ${ }^{129}$ The most that a pharmaceutical manufacturer can expect from these advertisements is to stimulate an office visit and to skew any patient role in choosing between treatment modalities. 130

In contrast, a pharmaceutical manufacturer's web presence, marketing and consumer-patient interaction is far more robust and potentially insidious. 131 A content-rich, interactive website threatens to replace much of physician-patient dialog, leaving the professional in a more passive role.132 As such the webmarketing of pharmaceuticals must trigger a fundamental reassessment of key

conference on Internet content). See also Promotion of FDA-Regulated Medical Products on the Internet; Notice of Public Meeting, 61 Fed. Reg. 48,707 (1996) (announcing an FDA sponsored public meeting to discuss issues related to the promotion of FDA-regulated medical products on the Internet with the purpose of guiding the FDA in policy decisions on the promotion of drugs on the Internet); Unified Agenda of Federal Regulatory and Deregulatory Actions 63 Fed. Reg. 61,680 (1998) (requiring the semiannual publication of an agenda that summarizes current rulemakings of the Department of Health and Human Services, including the emerging policy mandating more effective regulation of drugs and medical products).

123 See, e.g., Michael C. Allen, Comment: Medicine Goes Madison Avenue: An Evaluation of the Effect of Direct-To-Consumer Pharmaceutical Advertising on the Learned Intermediary Doctrine, 20 CAMPBELL L. REV. 113 (1997) (examining and evaluating the learned intermediary doctrine with regard to DTC advertising, focusing on an analysis of products liability principles); Teresa M. Schwartz, Consumer-Directed Prescription Drug Advertising and the Learned Intermediary Rule, 46 FOOD DRUG CosM. L.J. 829 (1991) (concluding that courts will be unwilling to recognize a new liability-expanding rule pertaining to increased advertising of prescription drugs to consumers); Lars Noah, Advertising Prescription Drugs to Consumers: Assessing the Regulatory and Liability Issues, 32 GA. L. REV. 141 (1997) (analyzing regulation and liability consequences of drug companies' media campaigns to sell more products). See also Lars Noah, Death of a Salesman: To What Extent Can the FDA Regulate the Promotional Statements of Pharmaceutical Sales Representatives?, 47 FOOD \& DRUG L.J. 309, 326, 334 (1992) (discussing FDA authority to control actions of pharmaceutical company "detail men").

124 See Rita Rubin, On-line Viagra worries medical boards, USA TODAY, Jan. 21, 1999, at DI (stating that as increasing numbers of websites offer "on-line consultations" for Viagra, medical licensing officials are studying ways to stop them).

125 See Frye v. Medicare-Glaser Corp., 605 N.E.2d 557 (IIl. 1992) (holding that a pharmacist and pharmacy were not negligent in warning of a drug's dangerous side effects).

126 See, e.g., CyberPharmacy, (visited Feb. 27, 1999) <http://www.cyberpharmacy.com>; Drugstore.com (visited Feb. 27, 1999) <http://www.drugstore.com/index.html>. See generally Matt Richtel, A Prescription for Success, N.Y. TIMES, Jan. 24, 1999, at B10 (discussing the founders of Drugstore.com); Bob Tedeschi, Want to Be an Online Drugstore? Take a Number, N.Y. TIMEs ON THE WEB, Feb. 2, 1999, (visited Mar. 28, 1999) <http://www.nytimes.com/library/tech/99/02/cyber/ commerce/02commerce.html> (showing the increasing popularity of online drugstore offerings); $\mathrm{Net}$ Pharmacies Raise Abuse Fears, Dallas MORNING NewS, Nov. 26, 1998, at 3C.

127 See Reichertz, supra note 122, at 304.

128 See Nordenberg, supra note 121 , at 7.

129 See id.

130 See Noah, Advertising Prescription Drugs to Consumers, supra note 123, at 150.

131 See id. at 153-54.

132 See Allen, supra note 123, at 118-19. 
liability doctrines that, heretofore, have been premised on a limited level of manufacturer-patient interaction. ${ }^{133}$ One possible liability scenario is of a drug manufacturer's marketing overreaching into overpromotion, and essentially nullifying otherwise adequate warnings. ${ }^{134}$ The more likely immediate scenario, and the one this Article will concentrate on here, is the dismantling of the learned intermediary doctrine. 135

\section{A. Pharmaceutical Marketing on the Web}

The search engine Yahoo! offers more than 1200 listings for pharmaceutical companies. 136 More discrete sources can link you directly to the 70 or so multinational pharmaceutical companies that have a web presence. ${ }^{137}$ As always, a number of business models are being explored. 138

Most major pharmaceutical companies have what are known as corporate sites. ${ }^{139}$ A few companies have begun to work with vertical portals, a prime example being the Pfizer site Exploring Your Health Online. 140 The site itself notes: "Pfizer is proud to bring you this friendly guide to researching health topics using the Internet."141 The site contains a wealth of information for those seeking to find health or disease information on the web. The site seems to studiously avoid direct marketing or promotion of Pfizer products, although each page contains a link to the Pfizer corporate site from which the user can navigate to individual product information. It carefully precedes every external link with a disclaimer, "You are now leaving www.pfizer.com/exploringhealth. Links to these outside sites are provided as a resource to the viewer."142

A particularly popular model is the consumer-oriented, product-specific site. For example, the Schering-Plough Corporation website, 143 while including news releases concerning the progress of drugs in the FDA regulatory process, directs surfers to what it describes as product-related websites. The portal site for these is the "Health Care Homepage, brought to you by Schering-Plough," with a separate surfer-friendly uniform resource locator (URL). 144 From the portal you can visit various zones such as Allergy Relief or Skin Cancer, again each with distinct userfriendly URLs. ${ }^{145}$ For example, the Skin Cancer site contains general health

133 See id. at 120.

134 See, e.g., Stevens v. Parke Davis \& Co., 507 P.2d 653 (Cal. 1973) (finding a pharmaceutical company liable for overpromotion of a drug).

135 See generally Allen, supra note 123 (discussing the effects of DTC pharmaceutical advertising on the leamed intermediary doctrine). Health>.

136 See Yahoo! (visited Jan. 26, 1999) <http://dir.yahoo.com/Business_and_Economy/Companies/

137 See Pharmaceutical Companies on the World Wide Web (visited Feb. 26, 1999) <http://members.aol.com/pharminf/ph_listl.html>.

138 See generally Merck (visited Feb. 26, 1999) <http://www.merck.com> (containing aspects of corporate, vertical portal and product-related advertising models).

139 See supra note 137. explore>.

140 See Exploring Your Heallh Online (visited Feb. 26, 1999) <http://www.pfizer.com/kpw/

141 See id.

142 For example, from the Exploring Your Health Online site, if you choose the Viagra hyperlink, you will be presented with the disclaimer. See External Link Page (visited Feb. 28, 1999) <http://www.pfizer.com/kpw/explore/cgi-bin/xlink/nph-xlink.cgi?link=http://www.pfizer.com>.

143 See Welcome to Schering Plough! (visited Feb. 24, 1999) <http://www.sch-plough.com>.

144 See Health Care Homepage (visited Feb. 24, 1999) <http://www.myhealth.com>.

145 See Welcome to Claritin.Com (visited Feb. 24, 1999) <http://www.allergy-relief.com>; 
information such as a Guide to Sun Safety, 146 but primarily provides information for potential or current users of the Schering-Plough prescription drug Intron. Similarly, although the Allergy Relief zone contains general consumer-oriented information such as Learn About Allergies!,147 its primary purpose appears to be marketing and supporting the Schering-Plough prescription drug Claritin family. ${ }^{148}$

Software companies once placed their documentation in manuals shipped with their software and provided customer assistance through telephony-based support. Today, both documentation and support are provided via the web. In the case of drug companies, consider again the Schering-Plough Allergy Relief zone discussed above. 149 Of most interest are the patient package inserts (PPIs), 150 or patient inserts (PIs), on this site.151 In fact, across all manufacturers' sites, the surfer can now expect to find full prescribing information for most heavily marketed prescription drugs. 152

\section{B. DOWNLOADING DTC INTO THE LEARNED INTERMEDIARY DOCTRINE}

As previously noted, the contemporary learned intermediary doctrine operates to immunize drug manufacturers facing failure to warn products liability theory. ${ }_{153}$ Modern DTC marketing, particularly web marketing, threatens this immunity. The learned intermediary doctrine is premised on the idea that the consumer of a prescription 154 drug, rather than the provider's patient, is in reality the prescribing health care provider. According to this theory, any warning duties owed by the manufacturer are owed exclusively to the provider. Once applied, the doctrine operates as an immunity because its practical effect is to deny the consumer-patient a product warning claim against the manufacturer. The implication is that the patient must establish a failure to wam or lack of informed consent against the prescribing physician, suits with a relatively low rate of recovery compared with product

Welcome to the Skin Cancer Zone! (visited Feb. 24, 1999) <http://www.skin-cancer.com/index.htm>. From Welcome to the Skin Cancer Zone!, one can access the consumer-oriented page, see Skin CancerConsumer Zone (visited Feb. 24, 1999) <http://www.skin-cancer.com/consumer/con_indx.htm>.

146 See Skin Cancer-Guide to Sun Safety (visited Feb. 24, 1999) <http://www.skin-cancer.com/ consumer/sun_sfty/guide/guide.htm>. index.htm>.

147 See Welcome to Claritin.Com (visited Jan. 26, 1999) <http://www.allergy-relief.com/leam/

148 See Welcome to Claritin.Com (visited Jan. 26, 1999) <http://www.allergy-relief.com/info/ index.htm>.

149 See supra note 144 and accompanying text.

150 See McKee v. American Home Prods. Corp., 782 P.2d 1045 (1989), stating:

In 1980, the FDA adopted regulations requiring patient package inserts (PPI) directed to the consumer. These were information leaflets, in lay language, to be produced by manufacturers and distributed by pharmacists at the time a prescription was filled. 40 Fed. Reg. 60,754 (1980). This program was rescinded, however, in 1982. 47 Fed. Reg. 39,147 (1982). Patient inserts are still required for oral contraceptives and several other drugs ....

782 P.2d at 1055 .

151 See Welcome to Claritin.Com (visited Feb. 25, 1999) <http://www.allergyrelief.com/pi/index.htm>. Patient inserts are also available for the medication Viagra, see Viagra (visited Feb. 26, 1999) <http://www.viagra.com/hcp/pro_pack_insert.htm>.

152 See Celebrex (visited Jan. 26, 1999) <http://www.celebrex.com/pi.htm> (manufaclured by Pfizer Inc.).

153 See Reyes v. Wyeth Labs., 498 F.2d 1264, 1276 (5th Cir. 1974); Basko v. Sterling Drug, Inc., 416 F.2d 417, 426 (2nd Cir. 1969); McKee v. Moore, 648 P.2d 21, 23 (Okla. 1982); Terhune v. A.H. Robins Co., 577 P.2d 975, 977 (Wash. 1978).

154 A different rule pertains to over-the-counter products. See Torsiello v. Whitehall Lab., 398 A.2d 132, 136 (N.J. Super. Ct. App. Div. 1979). 
liability claims. ${ }^{155}$ As the court in Tracy v. Merrell Dow Pharmaceuticals, Inc., ${ }^{156}$ noted:

The rationale behind these holdings is that the physician stands between the manufacturer and the patient as a learned intermediary. The physician has the duty to know the patient's condition as well as the qualities and characteristics of the drugs or products to be prescribed for the patient's use. The physician is in the best position, therefore, to balance the needs of patients against the risks and benefits of a particular drug or therapy, and then to supervise its use.157

Three interconnected rationales are captured by the Tracy court's statement. First, there is a physician or learned intermediary. 158 Second, the learned intermediary is in "the best position to balance the needs of patients against the risks and benefits" of the drug. 159 Third, any such learned intermediary in reality is standing "between the manufacturer and the patient."160 The generally accepted exceptions to the learned intermediary doctrine have developed from negating the second or third rationales. Indeed, the most widely accepted exception is based on the correlate to the first premise, there was no intermediary or at least no learned intermediary: a scenario commonly noted in mass immunization cases. 161

The next most familiar, albeit patchily recognized, ${ }^{162}$ exception to the application of the learned intermediary doctrine is based on the correlate to the second rational. 163 Thus, where the setting for the drug's distribution essentially negates the possibility for individualized risk-benefit analysis by the drug dispenser, the learned intermediary, the warning should be issued directly to the patient. The

155 There may be other variants if the information proves lacking. See Washington State Physicians Insurance Exchange \& Assoc. v. Fisons Corp., 858 P.2d 1054 (Wash. 1993) (describing a case where a physician brought an action against a pharmaceutical manufacturer for allegedly failing to warn him about a possible adverse reaction to the drug by his patient).

156569 N.E.2d 875 (Ohio 1991).

157 See id. at 878. Later the court also noted: "The learned intermediary doctrine achieves a proper allocation of responsibility since not all patients are alike and it is the physician who best knows the patient." Id. "[C]hoice . . . [of the learned intermediary] is an informed one, an individualized medical judgment bottomed on a knowledge of both patient and palliative." Reyes v. Wyeth Labs, 498 F.2d 1264, 1276 (5th Cir. 1974).

158 Tracy, 569 N.E.2d at 878.

159 Id.

160 See id.

161 See Brazzell v. United States, 788 F.2d 1352, 1357 (8th Cir. 1986). See also Mazur v. Merck \& Co., Inc., 964 F.2d 1348, 1355 (3d Cir. 1992). The mass immunization exception is better thought of as one context where a prescription dnig manufacturer is obligated to wam users directly of the facts that make its product dangerous. See id. at 1355 . That is, it restores the prescription drug manufacturer's duty to warn users directly, which is satisfied indirectly where the prescription drug manufacturer provides an adequate warning to a learned intermediary, because the rationale supporting the leamed intermediary rule buckles where prescription drugs are dispensed without an individualized medical balancing of the risks and benefits to the user. See id.

162 See West v. G.D. Searle \& Co., 879 S.W.2d 412, 414 (Ark. 1994), holding that:

The applicable Food and Drug Administration regulation requires a manufacturer to ship a leaflet or pamphlet to the dispenser which fully informs the patient of the benefits and risks involved in the use of oral contraceptives.... The duty imposed on Searle was to include this information, using the language required by the Food and Drug Administration, when it shipped the product to the dispenser.

Id. (emphasis in original)

163 Cf. RESTATEMENT (THIRD) OF TORTS $\$ 6 \mathrm{cmt}$. e (1998) (stating the rationale for this exception is that "wamings should be given directly to patients when government regulations so require."). 
classic example of this exception's application is the oral contraceptive. 164 In such a case, any risk-utility analysis undertaken should require the processing of information that is split between the provider and the patient. For example, a likely scenario would be that the physician has information about the patient's health and pharmacology, while the patient has information about social, sexual and personal choices. ${ }^{165}$ In MacDonald v. Ortho Pharmaceutical Corp., 166 the court noted:

The oral contraceptive thus stands apart from other prescription drugs in light of the heightened participation of patients in decisions relating to use of "the pill"; the substantial risks affiliated with the product's use; the feasibility of direct warnings by the manufacturer to the user; the limited participation of the physician (annual prescriptions); and the possibility that oral communications between physicians and consumers may be insufficient or too scanty standing alone fully to apprise consumers of the product's dangers at the time the initial selection of a contraceptive method is made as well as at subsequent points when alternative methods may be considered. We conclude that the manufacturer of oral contraceptives is not justified in relying on warnings to the medical profession to satisfy its common law duty to warn, and that the manufacturer's obligation encompasses a duty to warn the ultimate user. Thus, the manufacturer's duty is to provide to the consumer written warnings conveying reasonable notice of the nature, gravity, and likelihood of known or knowable side effects, and advising the consumer to seek fuller explanation from the prescribing physician or other doctor of any such information of concern to the consumer. 167

Overall, this seems to be a sounder rationale for these exceptional cases than government-mandated communication of the patient information, the PI or PPI, directly to the patient. 168

In contrast, in a web-marketing type of case, the correlate to the third rationale should be scrutinized-that there is no learned intermediary standing between the manufacturer and the patient. ${ }^{169}$ Recall Mazur v. Merck \& Co.,170 where the court refused to apply the learned intermediary rule because the manufacturer had foreseen a mass immunization scenario. As the Mazur court noted "Prescription drug manufacturers are charged with knowledge of the distribution system in which their products are sold."171 In a direct web-marketing scenario, the same reasoning as in

164 See MacDonald v. Ortho Pharm. Corp., 475 N.E.2d 65 (Mass. 1985). In MacDonald, the court held that: (1) a manufacturer of oral contraceptives owes direct duty to a user to warn of dangers inherent in use of contraceptives; and (2) a manufacturer's compliance with FDA guidelines does not necessarily shield it from liability for failing to provide adequate warnings. Id. at 65-66.

165 See Hill v. Searle Labs., 884 F.2d 1064 (8th Cir. 1989); Humes v. Clinton, 792 P.2d 1032 (Kan. 1990); see also MacDonald, 475 N.E.2d at 69 (finding that "the healthy, young consumer of oral contraceptives is usually actively involved in the decision to use "the pill'"); Odgers v. Ortho Pharm. Corp., 609 F. Supp 867, 878 (E.D. Mich. 1985) (finding that "a patient does not rely on the physician to nearly the same degree when it comes to choosing a method of contraception as in a decision regarding a therapeutic drug").

166475 N.E.2d 65.

167 Id. at 70.

168 See RESTATEMENT (THIRD) OF TORTS, $\$ 6 \mathrm{cmt}$. e.

169 See Mazur v. Merck \& Co., 964 F.2d 1348, 1356 (3d Cir. 1992).

170964 F.2d 1348 (3d Cir. 1992).

171 Id. at 1363 . 
Mazur should apply. By providing decision-related information, the web-marketing manufacturer has purposefully, or at least foreseeably, circumvented the learned intermediary who, consequently, is distanced from the patient's decision-making processes.

While the exact issue has not come up for decision, 172 a series of judicial comments seem to support the position that direct web-marketing may negate the Learned Intermediary doctrine. Take, for example, Tracy, 173 wherein the plaintiff made the argument, albeit a losing one, that the physician was acting as an agent for the manufacturer rather than a true learned intermediary. 174 A comment by the Tracy court, in response to the plaintiff's argument that the learned intermediary was not applicable to investigational drugs, is telling:

Typically, prescription drugs (whether FDA approved or in the investigational study phase) do not come to the patient in retail containers with full warning enclosures. Whether the drug is under investigation or FDA approved, it is the physician who selects it as appropriate for the patient. It is the physician who has the contact and relationship with the patient. ${ }^{175}$

A similar theme runs through the intrauterine device (IUD) case of Hill $v$. Searle Laboratories. ${ }^{176}$ The court stated:

Applying this test to the instant facts, we believe that IUDs, like other forms of birth control, are atypical from most prescription drug products because the treating physician generally does not make an intervening, individualized medical judgment in the birth control decision. Typically, the physician makes the decision of whether a particular treatment is necessary and desirable. In the case of birth control, however, the patient makes an independent decision as to whether she desires a prescription drug for birth control, and if so, which method she prefers, with only limited input from the prescribing physician. Several factors explain this reversal of roles. First, birth control is a private and personal matter involving a decision that is often dependent on factors to which the physician is not privy. In many cases, the patient makes her choice based on effectiveness, convenience or cost, rather than medical necessity. While a physician may recommend one method over another, the final choice remains that of the woman. Second, [defendant manufacturer] marketed the product with the idea of convincing women to choose the CU-7. Furthermore, beyond the initial treatment, there is little to no contact between the physician and the patient regarding the choice and the risks of using IUDs . . . . Recognizing that these factors limit the role that a

172 See In re Norplant Contraceptive Prods. Liab. Litig., 955 F. Supp 700 (E.D. Tex. 1997) (arguing unsuccessfully that direct web marketing may negate the learned intermediary doctrine) aff $d$, 165 F.3d 374 (5th Cir. 1999) (holding that Texas' leamed intermediary doctrine precludes manufacturer liability).

173569 N.E.2d 875 (Ohio 1991).

174 See id. at 879; see also Lars Noah, Death of a Salesman, supra note 123, at 310-12 (noting that information provided by pharmaceutical sales personnel "has the most significant impact on doctors' prescribing habits, outweighing the effects of post-graduate education, advertising, journal articles and direct mailings").

175 Tracy, 569 N.E.2d at 880 (emphasis added).

176884 F.2d 1064 (8th Cir. 1989). 
physician plays in determining the necessity and desirability of birth control, and the fact that physicians are inundated with information about various prescription drug products, we think that in the case of IUDs, prescribing physicians do not make an individualized medical judgment. Thus, Hill's treating physician was not an intervening party between herself and Searle. It was feasible to warn Hill. Moreover, such warning is required by FDA regulation. Therefore, the trial court erred in applying the learned intermediary rule to the facts of this case. 177

A duty to adequately warn the patient directly, the inapplicability of learned intermediary, is also supported by the Third Restatement of Torts. 178 It states:

A prescription drug or medical device is not reasonably safe because of inadequate instructions or warnings if reasonable instructions or warnings regarding foreseeable risks of harm are not provided to: ...

(2) the patient when the manufacturer knows or has reason to know that health care providers will not be in a position to reduce the risks of harm in accordance with the instructions or warnings. ${ }^{179}$

Finally, additional support for the proposition that direct marketing practices significantly undercut traditional defense arguments can be drawn from the words of a New Jersey court discussing the liability of a nonprescription drug manufacturer:

[W]e perceive the rule applicable to over-the-counter drugs as requiring the consumer to be adequately warned by the manufacturer of all known specific and appreciable inherent product dangers so that he can protect himself from the risks of use whether or not he consults a physician, and this is precisely because he is likely to use an over-thecounter product based on his own judgment, molded by advertising, and without ever consulting a physician at all. The point, of course, is that while the distinction in basic marketing techniques between prescription and nonprescription drugs supports a dichotomy as to who in each case must receive the warning, it does not support a dichotomy as to the nature or function of the warning, whether to physician or layman. The physician obviously must be sufficiently warned so that he may prescribe medication after intelligently evaluating its benefits and risks. A consumer of over-the-counter drugs is, as it were, selfprescribing and is intended, expected, and indeed encouraged by the drug industry to do so. He must, therefore, also be given such information by the manufacturer as will permit him to self-prescribe with a minimum of risk. 180

177 Id. at 1070-71 (footnotes and citation omitted); cf. In re Norplant Contraceptive Prods. Liab. Litig., 165 F.3d at 379 (finding that physicians play a significant role in prescribing Norplant and in educating patients about its use, therefore the leamed intermediary doctrine is still applicable); see also In re Norplant Contraceptive Prods. Liab. Litig., 955 F. Supp 700 (containing arguments from earlier proceedings where the plaintiffs' argument that DTC promotion undercuts the rationale of the leamed intermediary doctrine and estops defendants from relying on the intermediary as an independent causc and from asserting such a defense was not considered on the merits). But see Humes v. Clinton, 792 P.2d 1032 (1990) (holding that the leamed intermediary doctrine relieves manufacturer of intrauterine device (IUD) of duty to wam patients of risks involved).

178 RESTATEMENT (THIRD) OF TORTS, § 6(d).

179 Id. (emphasis added).

180 Torsiello v. Whitehall Labs., 398 A.2d 132, 139-40 (N.J. 1979). 


\section{UNCHARTED WATERS: ADVICE AND CONTENT SITES}

There is some substance to the argument that many of the web-based marketing activities of health care institutions and pharmaceutical manufacturers merely replicate real space models. Many such activities are little more than media translations of existing marketing practices, some no more than a print brochure or DTC copy already contemplated by industry regulators are now mounted on a website. 181 There can be no debate, however, that with emergent advice and content sites the web is truly innovating and creating a phenomenon with considerable disanalogies to real world marketing. Not surprisingly, such sites hold the potential for some of the most difficult legal issues. ${ }^{182}$

Needless to say, within the care or treatment advice and content genre, there are several interesting models with possible legally significant differences. For example, the pure marketing or contact model suggests that a physician-patient relationship will be created prior to advice, diagnosis or treatment. As such, the web is arguably merely being used for marketing, and real space malpractice law can be applied to issues that follow consummation of the physician-patient relationship.

Take as an example CyberDocs, ${ }^{183}$ where "the doctor is always in," and which describes itself as "the premiere Internet site for providing "live' patient care on the World Wide Web."184 As the service notes:

With CyberDocs, you can consult a physician from the convenience of your own home, from anywhere in the world!

U.S. trained, board-certified CyberDocs are available in various specialties, depending on your geographic locale, and are available by appointment, to address your medical needs via interactive keyboard chat and/or audiovideoconferencing. 185

Of course, even with this model, there will be interesting representation, even warranty issues surrounding the marketing context. Equally, various standard of care, not to mention jurisdictional, issues will arise regarding such "keyboard" medicine. Where the web opens up unique issues, however, is in the provision of medical content that does not flow from a colorable physician-patient relationshipa context that in cyberspace maps to advice, ${ }^{186}$ chat ${ }^{187}$ or diagnosis ${ }^{188}$ sites. ${ }^{189}$ As

181 Of course, today's websites go far beyond any such transliteration. The technological aspects, the interaction, targeting, personalization, etc., combined with the growing "stickiness" of such endeavors, suggests that this is marketing of an altogether different quality, intensity, targeting and penetration.

182 There are already reports of serious problems with online advice. See, e.g., Let the Surfer Beware, NewsweEk, Nov. 16, 1998, at 90; cf. Cyberdoctor Gets High Marks For His Pediatric Advice On The Internet; Colleague Says Column Is An Asset To Parents And Physicians Alike, ST. LouIS PosTDISPATCH, Nov. 8, 1998, at C13 (highlighting the story of the highly successful Ask the Webdoctor site that gives concerned parents pediatric health advice and information); see also Diane Jennings, Bitter Pill to Swallow: 'Cybermedicine' Simplicity has Fans but Raises Concerns, Dallas MORNING News, Nov. 6, 1998, at 1 A (emphasizing both the popularity of cybermedicine, and the problem of patients relying on medical advice from physicians they have never met); Docs Explore whether Online Medicine is Good Medicine, supra note 27.

183 Cyberdocs (visited Mar. 5, 1999) <http://www.cyberdocs.com>. See generally Cybermedicine seen as unhealthy by some; Concerns voiced over diagnosing ills, prescribing medicine on 'Net, Boston GlOBE, Aug. 6, 1998, at Cl (specifically discussing Cyberdocs, its practices and principles).

184 Cyberdocs (visited Mar. 5, 1999) <https://www.cyberdocs.com/sponsorship.htm>.

185 Id. (visited Jan. 25, 1999)<http://www.cyberdocs.com/>.

186 See, e.g., Yahoo! (visited Mar. 5, 1998) <http://dir.yahoo.com/Health/Advice>.

187 See, e.g., Yahoo! (visited Mar. 5, 1998) <http://dir.yahoo.com/Health/Chat>.

188 See, e.g., Yahoo! (visited Mar. 5, 1998) <http://dir.yahoo.com/Health/General_Health>.

189 The web is also alive with physician screening services, advice sites aimed more at the 
such, the primary focus of this section is to examine the potential liability of health care providers, or apparent professional providers, who establish themselves in cyberspace and thus attract cybercontact.

In what is still an immature area of web activity, there are some fascinating technology or business models are being examined. For example, telemedical.com 190 uses an extranet 191 model to link patients and physicians, patient records, products and services. ${ }^{192}$ Go Ask Alice!193 is an advice site operated by Columbia University's Health Education Program. It consists of an anonymous web forum providing "factual, in-depth, straight-forward, and nonjudgmental information to assist readers' decision-making about their physical, emotional, and spiritual health."194 Emedicine ${ }^{195}$ has corporate sponsors, including pharmaceutical and medical device manufacturers, and promises "[f]ree online medical textbooks for physicians, veterinarians, medical students, physician assistants, nurse practitioners, nurses and the public."196 Finally, consider Optum, 197 a back-end provider of "health and wellbeing support services" that health care providers can integrate into their products. 198

Beyond these existing models, we will also see a myriad of new manifestations of cybermedicine. These will include the simplest form of web content such as a health-related "how to" web page, advice given by one nonprofessional participant to another participant on a board/web-forum sponsored by an MCO or pharmaceutical manufacturer ${ }^{199}$ and the eventual provision of "professional" medical advice by interactive wizards. 200

Various liability fact patterns will fall out of these advice, chat and diagnosis sites. Many will be preceded by the formation of a traditional physician-patient relationship and are likely to attract real space analysis. Some will be "process" complaints that examine the way the relationship was formed rather than, necessarily, the quality of the care that resulted.201 A small number, almost

industry, see Physician Profile Services (visited Nov. 8, 1998) <http:/dir.yahoo.com/Business_and_Economy/ Companies/Health/Providers/Physician_Profile_Services>.

190 (visited Feb. 6, 1999) <http://www.telemedical.com/Telemedical/library.html>.

191 "An extranet is a private network that uses the Internet protocols and the public telecommunication system to securely share part of a business's information or operations with suppliers, vendors, partners, customers, or other businesses." (visited Feb. 6, 1999) <http://www.whatis.com/extranet.htm>.

192

The Cyberspace Telemedical Office is designed to be used by individuals, families, communities, and healthcare professionals ... . Guests are able to store up to 3.0 Megabytes of Their Personal Health Record and browse a growing list of healtheare information and products. However, paying or sponsored members have access to premium personalized services, publications, and online ordering of products.

Id. (visited Feb. 6, 1999) <http://www.telemedical.com/indexwb.htm>.

193 Go Ask Alice! (visited Feb. 6, 1999) <http://www.goaskalice.columbia.edu/about.html>.

194 See id.

195 Emedicine (visited Feb. 6, 1999)<http://www.emedicine.com/index.html>.

196 See id.

197 Optum (visited Feb. 6, 1999) <http://www.optumcare.com/index.html>.

198 Optum (visited Feb. 6, 1999) <http://www.optumcare.com/about/overview/index.html>.

199 See Doclor's Guide (visited Mar. 17, 1999) <http://www.docguide.com>.

200 See, e.g., the Condom Wizard at <http://www.condomania.com/cgi-bin/SonCart.exe/catalog/ wizard/cwiz.shtml? L+condomaniataaaa5137>, part of the Condomania site (visited January 23, 1999) $<$ http://www.condomania.com>.

201 See, e.g., Bloskas v. Murray, 646 P.2d 907 (Colo. 1982). A physician recommended specific surgery to a patient, falsely representing that he had performed the same operation on three other patients and that all had had successful results. See id. at 910 . In addition, he assured the patient that if the surgery were unsuccessful, the patient should not worry about amputation. See id. Contrary to his 
inevitably, will involve antisocial conduct such as an intentional or fraudulent misrepresentation.202 As the genre matures, the majority of cases, however, will involve courts being asked to impose liability for nonintentional supply of poor quality advice or content. Most cases will be brought utilizing negligence or negligent misrepresentation theories. However, a few plaintiffs may seek a warranty or products liability characterization.

In general, plaintiffs contemplating causes of action premised on substandard cybermedical advice will have little to work with. Analogous real space, typically print, cases involving claims for defective content generally have been unsuccessful.203 However, some more successful claims have been brought on warranty and products liability theories, albeit on facts that do not translate easily into cyberspace. 204

Negligence claims involving advice or content generally have stumbled at the "duty" hurdle.205 Courts have had doubts as to the issue of causation and the burden that an imposed duty would otherwise place on the defendant class. Regarding the former, consider Roman v. New York, 206 holding that Planned Parenthood was not liable for a misstatement in a pamphlet about contraception.207 The court stated:

Not every negligent statement is actionable. A defendant will only be held answerable where it is bound by some relational duty arising out of a public calling, contract or other. This court need not decide whether a relational duty would have existed if plaintiff Carmen Roman had sought out Planned Parenthood's advice. She did not. The evidence is clear and overwhelming that plaintiff sought the advice of friends and relatives and relied on the knowledge of the physicians and staff at Queens General Hospital. She did not go to defendant and defendant did not contact her. Their sole relationship is her fortuitous receipt of defendant's booklet at the hospital. That defendant pointedly intended the booklet to provide information to the general public, including plaintiff, and the fact that it could have reasonably foreseen plaintiff's reliance thereon, does not change the result. One who publishes a text cannot be said to assume liability for all "misstatements," said or unsaid, to a potentially unlimited public for a potentially unlimited period. Thus, the relational duty sufficient to

statement, the physician had never before personally performed this type of surgery. In reliance on these statements, the patient consented to the surgery, but it proved unsuccessful, ultimately resulting in amputation of the patient's foot. See id. at 909 . The court rejected the plaintiff's assertion that the trial court's instructional error led to the jury's rejection of his claim of malpractice based on a lack of informed consent. See id. However, a majority of the court concluded that a claim for negligent misrepresentation was not subsumed by plaintiff's malpractice claim and that the trial court erred in refusing to submit such a claim for jury consideration. See id. at 914; see also Annotation, Medical Malpractice: Liability Based on Misrepresentation of the Nature and Hazards of Treatment, 42 A.L.R.4th 543 (discussing negligent misrepresentation as a theory for relief).

202 See Barden v. HarperCollins Publishers, Inc., 863 F. Supp. 41, 45 (D. Mass. 1994). To recover for intentional fraudulent conduct, the plaintiff must prove that: "the defendant made a false misrepresentation of a material fact with knowledge of its falsity for the purpose of inducing the plaintiff to act thereon, and that the plaintiff relied upon the representation as true and acted upon it to his damage." Metropolitan Life Ins. Co. v. Ditmore, 729 F.2d 1, 4 (1st Cir. 1984) (citing Barrett Associates, Inc. v. Aronson, 190 N.E.2d 867, 868 (Mass. 1963).

203 See infra notes 207-31 and accompanying text.

204 See infra notes 239-51 and accompanying text.

205 See generally supra note 47.

206 Roman v. New York, 442 N.Y.S.2d 945 (Sup. Ct. 1981).

207 See id. at 948. 
give rise to a cause of action in negligent misrepresentation is not present. 208

In Bailey v. Huggins Diagnostic \& Rehabilitation Center, Inc., 209 the plaintiff had undertaken a course of extensive dental work principally for the removal of amalgam fillings. This work was performed allegedly as a result of the plaintiff reading the defendant's book in which he vigorously argued the minority professional position that amalgam caused injuries such as muscular deficiencies.210 The plaintiff also viewed a videotape of a local television documentary on the same subject in which the defendant had appeared.211

Although the actual circumstances surrounding the plaintiff's receipt of allegedly damaging information were somewhat more complex, the court framed the issue as: "the question presented by this appeal is the extent to which an author or interviewee on a public television program owes a legal duty of due care to those members of the public who may read the book or view the program."212 The court then stated:

[E]ven if it be assumed that some harm might have been foreseeable, we conclude that the social utility of encouraging authors to address issues of public concern, and the magnitude of the burden that would be imposed upon them if a duty of care were recognized, far outweigh the private interest of any individual reader, at least in those instances, as here, in which the published work implicates no illegal conduct.

The expression of opinions upon matters of public concern is the core value protected by the First Amendment. To subject authors of such opinions to the risk of multiple claims for personal injuries, at least in those instances, as here, in which the opinions do not address or impugn any specific individual, based solely upon the majoritarian view that the opinion is "false," would impose an intolerable burden upon the author of such opinions. And, the imposition of such a burden would have a ruinous and unjustifiable chilling effect upon free speech. 213

The defendant in Barden v. HarperCollins Publishers, Inc.214 had published a guide for victims of child sexual abuse. The book contained a list of attorneys who could be consulted to assist victims. ${ }^{215}$ The plaintiff, who read the book, complained that one of the listed attorneys was credited with false qualifications;216 said attorney having failed to perform legal services for the plaintiff notwithstanding a paid retainer. 217 The plaintiff's action was premised on negligence.218 The court granted the defense motion for summary judgment, 219 concluding:

208 Id. at $947-48$.

209 Bailey v. Huggins Diagnostic \& Rehabilitation Center, Inc., 952 P.2d 768 (Colo. App. 1997), reh' 'g denied (Colo. App. July 31, 1997), cert. denied (Colo. Feb. 23, 1998).

210 See id. at 770.

211 See id.

212 Id. at 772.

213 Id. at 773 (citation omitted).

214 Barden v. HarperCollins Publishers, Inc., 863 F. Supp. 41 (D. Mass. 1994).

215 See id. at 42.

216 See id.

217 See id.

218 See id.

219 See id. A similar fate befell the plaintiff's cause of action based on state deceptive trade 
Simply put, allowing the plaintiff to seek relief under a negligent misrepresentation claim would open a pandora's [sic] box that might be difficult to close. The burden placed upon publishers to check every fact in the books they publish is both impractical and outside the realm of their contemplated legal duties. Further, in the present case, it is clear that the defendant did not assume the duty to investigate. 220

Several other cases dealing with allegations of defective content also favor the defense. However, the reasoning in these might have had more to do with the particular type of defendant before the court rather than any general sense of immunity in advice or content cases. For example, the Barden court relied in large part on the leading case of Winter v. G.P. Putnam's Sons.221 Winter concerned The Encyclopedia of Mushrooms, a reference guide containing information on the habitat, collection and cooking of mushrooms. ${ }^{222}$ The plaintiffs alleged that some of the information contained was erroneous or misleading, resulting in their consumption of poisonous mushrooms. ${ }^{223}$ Although clearly a real space case, Winter provides a near-perfect virtual space hypothetical. However, the Winter court's reason for refusing to impose a duty of care on the defendant publisher was quite narrowly drawn:

We conclude that the defendants have no duty to investigate the accuracy of the contents of the books it publishes. A publisher may of course assume such a burden, but there is nothing inherent in the role of publisher or the surrounding legal doctrines to suggest that such a duty should be imposed on publishers. Indeed the cases uniformly refuse to impose such a duty. Were we tempted to create this duty, the gentle tug of the First Amendment and the values embodied therein would remind us of the social costs.224

A similar result was reached in Jones v. J.B. Lippincott Co.225 There, the publishers of a nursing textbook were held not liable to a nursing student who consulted their Textbook for Medical and Surgical Nursing, and treated herself for constipation with a hydrogen peroxide enema.226 The court held:

Author liability for errors in the content of books, designs, or drawings is not firmly defined and will depend on the nature of the publication, on the intended audience, on causation in fact, and on the foreseeability of damage. Publisher liability, on the other hand, has more clearly defined principles and is therefore more easily determined. If a publisher serves the function of publishing the contents of an author, other than one of its own employees for whom it would be liable under the doctrine of respondeat superior, it has no duty for the contents.227

Winter, Jones and Barden suggest, therefore, that a website publishing its own

practices legislation.

220 Id. at 45.

221 Winter v. G.P. Putnam's Sons, 938 F.2d 1033 (9th Cir. 1991).

222 See id. at 1034.

223 See id.

224 Id. at 1037; see also Demuth Dev. Corp. v Merck \& Co., 432 F. Supp. 990 (E.D.N.Y. 1977) (concerning an encyclopedia of chemicals and drugs).

225 Jones v. J.B. Lippincott Co., 694 F. Supp. 1216 (D. Md. 1988).

226 See id. at 1216.

227 Id. at 1216-17 (citations omitted). 
advice or content rather than that of a third party, such as an author supplier, may have some exposure relating to defective online content, a position that eerily resonates with some cyberspace-specific doctrine.228 Even the more obviously prodefense cases, such as Roman and Bailey, are premised essentially on the plaintiff being just one unidentified member of an undifferentiated pool of potential plaintiffs or readers. ${ }^{229}$ Such a rationale may not be as helpful to a web defendant using highly targeted marketing to specific plaintiffs identified via cookies 230 or site experience personalization.231

A few plaintiffs injured by information dressed up for a market, such as a book sold through retail channels, have sought to characterize the information as a product ${ }^{232}$ and the liability allocation model 233 as products liability. ${ }^{234}$ With some interesting exceptions that do not map well to cyberspace, most of the cases espousing a products, or products-analogous, theory have failed.235

228 See infra notes 296-303 and accompanying text.

229 See supra notes 38-39 and accompanying text.

230 Cookies are bits of information about users, stored on their computers' hard drives by websites, that enable those websites to remember users and their preferences. See PCWebopedia (visited Apr. 2, 1999) <www.webopedia.com/TERM/c/cookie.html>.

231

Personalization (sometimes called customization) generally refers to making a Web site more responsive to the unique and individual needs of each user.

This can be accomplished in a number of ways, some of which require the user's active involvement (typically through filling out a form or following a decision-tree set of questions). Other approaches operate behind the scenes, without relying on use input-by using cookies, for example, or by looking at an IP address and serving up content based on the user's browser.

Web Business-Personalizing your Web site-What is personalization? (visited May 19, 1999) $<\mathrm{http}: / / \mathrm{www}$.builder.com/business/personal/ss01.html>.

232 Several fascinating issues beyond the scope of this Article arise. See Cardozo v. True, 342 So.2d 1053, 1056 (Fla. Dist. Ct. App. 1977) (distinguishing the tangible portion of the book, the binding and printing, characterized a "good," from the thoughts and ideas contained therein).

233 See generally Nicolas P. Terry, Collapsing Torts, 25 CONN. L. REV. 717, 725-28 (1993) (discussing the strict liability allocation model).

234 See generally Charles Walter \& Thomas F. Marsteller, Liability for the Dissemination of Defective Information, 30 IEEE TRANSACTIONS ON PROF'L COMM., Sept. 1987, at 164 (discussing the requisite factors to prove a products liability claim). See also Pamela Samuelson, Liability for Defectlve Electronic Information, 36 COMM. ACM, Jan. 1993, at 21 (discussing the liability of software developers if their software injures a user).

235

Further, appellant's rationale - that appellees are liable because the State (a third party) relied on the publications to determine emission laws-is flawed. This reasoning is faulty because any duty owed would not be to appellant, but to those who actually relied on the work-in this case, the State.

Sinai v. Mitchell Books, No. 92-15442, 1993 WL 220260, at *1 (9th Cir. June 23, 1993) (Unpublished Disposition).

See Yanase v. Automobile Club of S. Cal., 212 Cal. App. 3d 468, 468 (Cal. Ct. App. 1989) (holding publisher of a tour guide not liable to the plaintiff killed in the parking lot of motel listed in guide); Walters v. Seventeen Magazine, 195 Cal. App. 3d 1119, 119 (Cal. Ct. App. 1987) (holding magazine not liable to the plaintiff who suffered from toxic shock syndrome from advertised tampon); Pittman v. Dow Jones \& Co., 662 F. Supp. 921, 922 (E.D. La. 1987) (holding the newspaper not liable for printing a fraudulent advertisement); Lewin v. McCreight, 655 F. Supp. 282, 282 (E.D. Mich. 1987) (holding the defendant not liable because defendant merely printed, not created, a book); Demuth Dev. Corp. v. Merck \& Co., Inc., 432 F. Supp. 990, 990 (E.D.N.Y. 1977) (granting summary judgment to defendant who published a chemical encyclopedia which allegedly contained a misstatement of a chemical's toxicity); Way v. Boy Scouts of America, 856 S.W.2d 230, 237 (Tex. Ct. App. 1993) (holding the magazine publisher not liable for the accidental shooting death of a 12-year old boy after he had read a shooting sports supplement in the defendant's magazine). See also Garcia v. Kusan, Inc., 655 N.E.2d 1290, 1290 (Mass. App. Ct. 1995) (holding the producer of a floor hockey game not liable 
A representative case is Birmingham v. Fodor's Travel Publications, Inc., 236 where the publisher of a travel guide was held to be under no duty to warn a reader of dangerous ocean surf conditions at a beach resort.237 The court summed up the national position as follows:

It appears from a review of relevant case law that no jurisdiction has held a publisher liable in negligence for personal injury suffered in reliance upon information contained in the publication, unless the publisher authored or guaranteed the information. Whether based on negligent misrepresentation or negligent manufacture of a defective product, the cases uniformly hold, for the same policy reasons, that, absent guaranteeing or authoring the contents of the publication, a publisher has no duty to investigate and warn its readers of the accuracy of the contents of its publications. 238

In opposition to the majority of cases refusing to apply product liability to information, whether tangible or not, there is a narrow group of cases favoring plaintiffs in cases concerning defective aeronautical charts. ${ }^{239}$ These cases were examined in Smith v. Linn,240 in which the publisher of a diet book entitled When Everything Else Fails . . . The Last Chance Diet was sued when a reader died of complications arising from the liquid protein diet featured in the book. The plaintiff brought a product liability action. 241 The plaintiff argued that the diet was a product, and the book was a PI.242 The court concluded: "Instructions by a manufacturer which accompany medication or use of certain marketed goods cannot be equated with publication of books which espouse a writer's theory, opinions or ideology."243 In holding that strict products liability doctrine was not applicable to a book, the court distinguished map and chart cases 244 as follows:

In those cases, extremely technical and detailed materials were involved, upon which a limited class of persons imposed absolute trust having reason to believe in their unqualified reliability. As such they took on the attributes of a product and are not protected by the First Amendment. 245

The most likely rationale for applying strict liability to an aeronautical chart is that it operates as a surrogate for, or as the functional equivalent of, physical

to the plaintiff who was injured when struck in the eye by hockey stick during a gym class).

236833 P.2d 70, 70 (Haw. 1992).

237 See id.

238 See id. at 75 (footnotes omitted) (emphasis added).

239 See Brocklesby v. United States, 767 F.2d 1288 (9th Cir. 1985); Saloomey v. Jeppesen \& Co., 707 F.2d 671, 676-77 (2nd Cir. 1983) (classifying charts as defendant's products); Fluor Corp. v. Jeppesen \& Co., 216 Cal. Rptr. 68, 68 (Ct. App. 1985). See also Halstead v. United States, 535 F. Supp. 782, 782 (D. Conn. 1982) (classifying navigational charts as products); Times Mirror Co. v. Sisk, 593 P.2d 924, 924 (Ariz. Ct. App. 1978) (holding that whether a navigational chart was unfit for purposes and whether misrepresentations of the defendant about the chart were proximate causes of the accident were jury questions).

240563 A.2d 123, 126 (Pa. Super. Ct. 1989).

241 See id. The plaintiff's action was premised on Second Restatement of Torts sections 388 and 390. See id. The Smith court was dismissive of the plaintiff's arguments based on exceptions to the

First Amendment and a negligent publication argument. See id. at 125-26.

242 See id. at 126; see also supra note 150 (discussing PPIs).

243 Smith, 563 A.2d at 126.

244 See, e.g., Kercsmar v. Pen Argyl Area Sch. Dist., 1 Pa. D. \& C.3d 1 (1976).

245 Smith, 563 A.2d at 127. 
products such as a compass, radar or navigational instrument.246 To phrase the argument slightly differently, the information in chart cases goes beyond ideas or expressions to a fixed representation or utilization of the same data.247 The Winter court fleshed things out further:

The purposes served by products liability law ... a are focused on the tangible world and do not take into consideration the unique characteristics of ideas and expression....

Although there is always some appeal to the involuntary spreading of costs of injuries in any area, the costs in any comprehensive cost/benefit analysis would be quite different were strict liability concepts applied to words and ideas. We place a high priority on the unfettered exchange of ideas. We accept the risk that words and ideas have wings we cannot clip and which carry them we know not where. The threat of liability without fault (financial responsibility for our words and ideas in the absence of fault or a special undertaking or responsibility) could seriously inhibit those who wish to share thoughts and theories. As a New York court commented, with the specter of strict liability, "[w]ould any author wish to be exposed . . . for writing on a topic which might result in physical injury? e.g. [sic] How to cut trees; How to keep bees?" One might add: "Would anyone undertake to guide by ideas expressed in words either a discrete group, a nation, or humanity in general?"248

Overall, the case law suggests that strict products liability is unlikely to be applied to injuries sustained because of defects in web-based content. Of course, one strain of products doctrine may be more obviously applicable. It should come as little surprise that the publisher who expressly guarantees the accuracy of a piece of information could attract liability. After all, such representational liability is premised on the guarantee, the warranty, rather than the intrinsic quality of the underlying product or service. ${ }^{249}$ In other words, while implied warranty claims will generally be duplicative of process-oriented negligence claims or strict liability defect allegations, a few bad content claims could be brought using express warranty doctrine, 250 essentially allegations of outcome warranty.251 However, as with many of the negligence cases discussed above, the only case really on point was primarily concerned with the potential liability of a publisher rather than the content creator, the author.

In Walters $v$. Seventeen Magazine,252 the plaintiff contracted toxic shock syndrome allegedly as a result of using a tampon advertised in the defendant's magazine. The court in affirming a dismissal noted, "Seventeen did not in any way

246 See Winter v. G.P. Putnam's Sons, 938 F.2d 1033, 1036 (9th Cir. 1991); Jones v. J.B. Lippincott Co., 694 F. Supp. 1216, 1217 (D. Md. 1988).

247 See Winter, 938 F.2d at 1036 (analogizing an aeronautical chart to a compass).

248 Id. at 1034-35 (citations omitted); accord Birmingham, 833 P.2d at 78.

249 See, e.g., Crocker v. Winthrop Labs, 514 S.W.2d 429, 433 (Tex. 1974) (predicating a drug manufacturer's liability on its misrepresentation that the drug was "free and safe from all dangers of addiction").

250 See, e.g., Sullivan v. O'Connor, 296 N.E.2d 183, 189-90 (Mass. 1973) (holding that, in an action by a professional entertainer against a surgeon for breach of a contract to improve the appearance of the plaintiff's nose in two operations, the plaintiff was entilled to recover not only her out-of-pocket expenses, but also for worsening of the appearance of her nose by the surgery and for pain and suffering and mental distress involved in a third operation).

251 See id.

252241 Cal. Rptr. 101 (Ct. App. 1987). 
sponsor or endorse products advertised in its pages. There was no representation of quality, no promotional effort, and no attempt to induce the public to buy Playtex tampons beyond merely printing the advertisement." 253

The Walters court also volunteered what could become something of a mantra for web content providers when it stated:

In the absence of any cause of action supported by traditional theories, we are loathe to create a new tort of negligently failing to investigate the safety of an advertised product. Such a tort would require publications to maintain huge staffs scrutinizing and testing each product offered. The enormous cost of such groups, along with skyrocketing insurance rates, would deter many magazines from accepting advertising, hastening their demise from lack of revenue. Others would comply, but raise their prices beyond the reach of the average reader. Still others would be wiped out by tort judgments, never to revive. Soon the total number of publications in circulation would drop dramatically. 254

Cyberspace and its applicable doctrines are many years short of maturity, yet it is not difficult to compose a tentative catalog of legal issues. It is difficult to believe any of the early cases involving allegations of advice site liability not featuring defense arguments as to First Amendment protection. Also inevitable will be arguments that such speech should be characterized as commercial.25s In addition, First Amendment claims will be met by conventional counter arguments such as defamation and fraud, 256 or speech directed to imminent lawless action. 257 Similarly, the exact relationship between First Amendment protection and the chilling effect of

253 Id. at 102. The court distinguished the leading case of Hanberry y. Hearst Corp., 81 Cal. Rptr. 519 (Ct. App. 1969), by noting that unlike Good Housekeeping magazine in Hanberry, the defendant in this case made no endorsement of a product's effectiveness. See Walters, 241 Cal. Rptr. at 102; see also McCollum v. Friendly Hills Travel Ctr., 217 Cal. Rptr. 919 (Ct. App. 1985) (holding that the defendant did not make any express or implied warranties regarding the safety of water skiing equipment by just telling the plaintiff of the availability of such equipment).

254 Falters, 241 Cal. Rptr, at 102-03.

255 See, e.g., Dun \& Bradstreet, Inc. v. Greenmoss Builders, Inc., 472 U.S. 749, 759 n.4 (1985) (discussing the reduced First Amendment protection that commercial speech receives); see also Ohralik v. Ohio State Bar Ass'n, 436 U.S. 447, 455-56 (1978) (finding a lawyer's solicitation of business to be unprotected commercial speech). For health-related cases, see Virginia State Bd. of Pharmacy v. Virginia Citizens Consumer Council, Inc., 425 U.S. 748, 770-73 (1976) (protecting a pharmacist's advertisement of drug prices, even though a state statute authorized revocation of licenses of clinical laboratories that advertised); Metpath Inc. v. Myers, 462 F. Supp. 1104, 1110 (N.D. Cal. 1978) (finding a First Amendment violation where a state statute authorized revocation of licenses of clinical laboratories that advertised). See also Missouri Dental Bd. v. Alexander, 628 S.W.2d 646 (Mo. 1982) (issue not reached). For a content-tort liability type case, see Hustler, 814 F.2d 1017 (5th Cir. 1987) cert. denied, the Fifth Circuit apparently viewed a mere "promotional device" as commercial speech in contrast with content disseminated for profit (814 F.2d at 1024) that could still qualify as noncommercial speech.

256 Zauderer v. Office of Disciplinary Counsel, 471 U.S. 626 (1985) (alleging that the defendant's advertisements were fraudulent and deceptive); Gertz v. Robert Welch, Inc., 418 U.S. 323 (1974) (alleging that the defendant's publishing of advertisements containing inaccuracies was defamatory); Beauhamais v. Illinois, 343 U.S. 250 (1952) (alleging that the defendant's actions constituted criminal libel); Schneider v. State, 308 U.S. 147 (1939) (alleging that the defendants violated ordinances designed to prevent litter and fraudulent solicitation).

257 See also Waller v. Osbourne, 763 F. Supp. 1144, 1152-53 (M.D. Ga. 1991) (granting summary judgment to the defendants where the plaintiffs failed to demonstrate the existence of a subliminal message, or that the defendant's music incited imminent lawless activity). 
exposure to post-publication civil liability likely will be explored.258 Equally, due regard must be had to long-stated judicial hesitance to impose negligence-based tort liability for speech or expression. As the Court of Appeals noted in 1927:

Not every casual response, not every idle word, however damaging the result, gives rise to a cause of action. . . . Liability in such cases arises only where there is a duty, if one speaks at all, to give the correct information. And that involves many considerations. There must be knowledge, or its equivalent, that the information is desired for a serious purpose; that he to whom it is given intends to rely and act upon it; that, if false or erroneous, he will because of it be injured in person or property. Finally, the relationship of the parties, arising out of contract or otherwise, must be such that in morals and good conscience the one has the right to rely upon the other for information, and the other giving the information owes a duty to give it with care.259

Finally, web risk managers must understand that information torts that have been relatively rare in real space likely will explode in virtual space. Of these, potentially the most interesting pure content scenarios are cases dealing with accurate but dangerous information. 260 Additionally, interactive sites, particularly those offering chat or forum features, will face claims based on alleged duties to protect other participants. 261

\section{MANAGING CYBER-MALPRACTICE EXPOSURE}

Because cyberspace liability exposure is a relatively new concept, managing web risks is clearly in its infancy. ${ }^{262}$ Regulatory agencies have been slow to react, ${ }^{263}$ and there are considerable doubts as to even telemedicine coverage under current malpractice liability policies. ${ }^{264}$ Indeed, at first sight, it seems that in their rush to

258 See, e.g., New York Times Co. v. Sullivan, 376 U.S. 254 (1964); McCollum v. Friendly Hills Travel Ctr., 217 Cal. Rptr. 919 (Ct. App. 1985); Hustler, 814 F.2d 1017; Alm v. Van Nostrand Reinhold Co., 480 N.E.2d 1263 (1985).

259 International Products Co. v. Erie R.R. Co., 155 N.E. 662, 664 (1927).

260 For example, Hustler, 814 F.2d 1017, concerned the plaintiffs' 14-year-old decedent who took his own life apparently attempting the practice of autoerotic asphyxia. He had read about the practice in a Hustler Magazine article entitled Orgasm of Death. See Rice v. Paladin Enterprises, Inc., 128 F.3d 233 (4th Cir. 1997), which concerned a book, HIT MAN: A TECHNICAL MANUAL FOR INDEPENDENT CONTRACTORS, which is also available for purchase over the web; see (visited Jan. 29, 1999) <http://www.paladin-press.com/Default.htm>.

261 In Doe v. America Online, Inc., 718 So. 2d 385 (Fla. Ct. App. 1998), the plaintiff's 11-yearold child was engaged by a pornographer who then distributed videotapes of the child engaged in sexual acts. See id. at 386. The pomographer, an America Online (AOL) subscriber, allegedly used AOL chat rooms to advertise and arrange the sale of the pornography. See id. It appears, however, that the materials were not displayed on or transmitted via AOL. The plaintiff sued AOL primarily on the basis that AOL breached an alleged duty to exercise reasonable care to ensure that its service not be used "to market and distribute child pomographic materials." See id. at 386. The Florida court did not reach the merits of the tort claim, dismissing all claims on the basis that AOL was protected by 47 U.S.C. $\$ 230$, see id., discussed at text accompanying note 298.

262 But see Kristin B. Keltner, Note, Networked Health Information: Assuring Quality Control on the Internet, 50 FED. COM. L.J. 417, 424-25 (1998) (noting that government has been protective of network health information consumers).

263 Cf. Federation of State Medical Boards of the United States, A Model Act to Regulate the Practice of Medicine Across State Lines: An Introduction and Rationale (visited Mar. 7, 1999) $<$ http://www.fsmb.org/telemed.htm> (noting that government support of telecommunications has risen recently).

264 See, e.g., The Western Governors' Association, Telemedic Action Report (1996) (visited Mar. 
construct a web presence, health care providers have made little effort to manage liability or financial exposure. In fact, risk management approaches are emerging, 265 though few of them seem destined for immediate success. This Article highlights four approaches toward managing the risks of health care providers in cyberspace: self-regulatory codes of conduct; disclaimers; site zoning; and the exploitation of the federal immunity from civil suit granted to certain web publishers.

\section{A. SELF-REGULATORY CODES OF CONDUCT}

There is an embryonic movement towards cybermedicine sites complying with self-regulatory codes of conduct. The leading advocate is the Health On the Net Foundation (HON), describes itself as "dedicated to realising the benefits of the Internet and related technologies in the fields of medicine and healthcare." "The purpose of HON is to advance the development and application of new information technologies, notably in the fields of health and medicine."266 HON promulgated its so-called Health On the Net Foundation Code of Conduct (HON Code), providing as follows:

1. Any medical/health advice provided and hosted on this site will only be given by medically/health trained and qualified professionals unless a clear statement is made that a piece of advice offered is from a non-medically/health qualified individual/organisation.

2. The information provided on this site is designed to support, not replace, the relationship that exists between a patient/site visitor and his/her existing physician.

3. Confidentiality of data relating to individual patients and visitors to a medical/health Website, including their identity, is respected by this Website. The Website owners undertake to honour or exceed the legal requirements of medical/health information privacy that apply in the country and state where the Website and mirror sites are located.

4. Where appropriate, information contained on this site will be supported by clear references to source data and, where possible, have specific HTML links to that data. The date when a clinical page was last modified will be clearly displayed (e.g. at the bottom of the page).

5. Any claims relating to the benefits/performance of a specific treatment, commercial product or service will be supported by

5, 1999) <http://www.health.state.nd.us/gov/hotnews/telemed.htm>:

There is significant uncertainty regarding whether malpractice insurance policies cover services provided by telemedicine. Telemedicine networks that cross state lines create additional uncertainties regarding the state where a malpractice lawsuit may be litigated and the law that will be used. Will the lawsuit be heard in the state of the provider, the patient, or in another state covered by the network? Which state's law will govern the case? Choice of venue and choice of law issues can have significant financial implications for the parties to litigation as states differ-in the statutory limits placed on the amount of malpractice awards ..... Governors should direct their state insurance commissions to review the current policies of the malpractice insurance industry with regards to telemedicine, and to recommend changes that encourage insurers to develop clear and consistent coverage policies.

Id. Note also that malpractice insurance tends to be state-centric, causing major coverage and ratesetting issues when patients' consultations defy real space national and international borders.

265 See Keltner, supra note 262, at 427-28 (citing encryption programs and disclaimers as protections).

266 About Health on the Net Foundation: Background (visited Mar. 7, 1999) <http:/www.hon.ch/ Global>. 
appropriate, balanced evidence in the manner outlined above in Principle 4.

6. The designers of this Website will seek to provide information in the clearest possible manner and provide contact addresses for visitors that seek further information or support. The Webmaster will display his/her E-mail address clearly throughout the Website.

7. Support for this Website will be clearly identified, including the identities of commercial and non-commercial organisations that have contributed funding, services or material for the site.

8. If advertising is a source of funding it will be clearly stated. A brief description of the advertising policy adopted by the Website owners will be displayed on the site. Advertising and other promotional material will be presented to viewers in a manner and context that facilitates differentiation between it and the original material created by the institution operating the site. 267

A growing number of cybermedicine sites now display the HON Code logo268 and purport to comply with the code. 269 As with all self-regulatory instruments, it will have its greatest impact in cyber-malpractice cases as evidence of feasible or customary practice.

\section{B. Disclaimers}

There seem to be two discernible trends in cybermedicine disclaimers: 270 whether viewed as exculpatory statements or preinjury releases. The first seems to assert few direct limitations on user rights but seeks to place the web content into a subordinate role in an overall provider-patient relationship. For example, a site might proclaim: "The health information contained herein is provided for educational purposes only and is not intended to replace discussions with a healthcare provider. All decisions regarding patient care must be made with a healthcare provider and consider the unique characteristics of each patient."27t

In contrast, a considerable number of cybermedicine sites now make use of

267 HON Code of Conduct (HON code) for Medical and Health Web Sites: Principles (visited Mar. 7, 1999)<http://www.hon.ch/Conduct.html>.

268 HON Code of Conduct (HON code) for Medical and Health Web Sites: Introduction (visited Mar. 7, 1999) <http://www.hon.ch/HONcode>.

269 See, e.g., The Breast Cancer Resource Guide for Massachusetts (visited Mar. 6, 1999) <http://www.breasted.org>; The Washington Home and Hospice of Washinglon (visited Mar. 6, 1999) <http://www.washingtonhome.org>. See also The Reynoldsburg. Ohio Lions Club (visited Mar. 6, 1999) <http://www.reynoldsburglions.org> (displaying little or no health or medical advice or links).

270 See Allina Disclaimer (visited Mar. 16, 1999) <http://www.allina.com/disclaimer.html>; Mayoclinic: Online Service Agreement, Agreement (visited Mar. 6, 1999) <http://www.mayohealth.org' mayo/common/htm/disclaim.htm>.

271 Viagra (visited Feb. 7, 1999) <http://www.viagra.com>. Part of the disclaimer published by Allina Health System states:

Any medical or health care advice provided and hosted on the Allina Health Village will only be given by medically trained and qualified professionals unless a clear statement is made that a piece of advice offered is from an otherwise qualified healtheare professional and/or healthcare organization. The information provided on this site is designed to support, not replace, the relationship that exists between a patien $/$ site visitor and his/her existing physician.

Any use by you of this website or the information contained in the website is at your own risk.

Allina Disclaimer, supra note 270. 
quite exhaustive disclaimers. What follows is from Glaxo Wellcome Inc., all of whose product pages link to a common page that is referred to by the hyperlink as "legal disclaimer and trademark information."272 However, when opened, the webpage is described as Copyright Info for Glaxo Wellcome Inc.273 Indeed, the first paragraph of that linked page does contain intellectual property information. However, the page then continues:

This publication is provided "AS IS" WITHOUT WARRANTY OF ANY KIND, EITHER EXPRESSED OR IMPLIED, INCLUDING, BUT NOT LIMITED TO, THE IMPLIED WARRANTIES OF MERCHANTABILITY, FITNESS FOR A PARTICULAR PURPOSE, OR NON-INFRINGEMENT. Some jurisdictions do not allow the exclusion of implied warranties, so the above exclusion may not apply to you.

The Web site was developed as a service provided by Glaxo Wellcome Inc. This Web site provides selected information available about a range of disease topics. Like any printed material, it may become out of date over time. It is important that consumers rely on the advice of a health care professional to employ good clinical judgment for the specific conditions of individual patients. This information is not intended to be a substitute for the advice of a health care professional, or a recommendation for any particular treatment plan. External sites are not necessarily endorsed by Glaxo Wellcome Inc.

Certain links on this site lead to resources located on servers maintained by third parties over whom Glaxo Wellcome Inc. has no control. As such, Glaxo Wellcome Inc. makes no representation as to the accuracy or any other aspect of the information contained on such servers. 274

Interestingly, few attempts seem to have been made at making agreement to a preinjury release a condition of site use or web community membership.275 of course, such a position would require navigation of the difficult areas of clickwrap276 or click-through 277 contracting. 278 Any examination of the legal effect of

272 See, e.g., Glaxo Wellcome, USA (visited Feb. 7, 1999) <http://www.gw-navelbine.com> (discussing the product Navelbine).

273 (visited Mar. 7, 1999) <http://www.imgw.com/copyrite.htm>.

274 Id. The Schering-Plough disclaimer takes a less rigorous approach, providing: Schering-Plough will use reasonable efforts to include accurate and up-to-date information on this site, but makes no representations or wartanties as to its accuracy or completeness. Access to and use of the content is at your own risk, and neither Schering-Plough nor any party involved in creating or delivering this site shall be liable to you for any damage of any kind arising out of your access, use or inability to access or use this site, or for any omissions or errors in its content.

Terms and Conditions (visited Mar. 24, 1999) <http://www.sch-plough.com/terms.html>.

275 See, e.g., Mayo Clinic: Online Service Agreement, supra note 270. This disclaimer ends with hyperlinks that state:

Laccept all of the foregoing terms either by clicking here or by any further use of the Service. Le not accept all of the foregoing terms.

Id.

276 Click-wrap is described as consumers on their computers clicking on a box marked "I Agree." See Click-wrap License Agreements (visited Mar. 17, 1999) <http://www.ljx.com/internet/ 0811 clickwrap.html>; see also Law Journal Extra! Law of the Internet (visited Mar. 6, 1999) 
disclaimers in provider liability cases primarily is informed by the decision in Tunkl v. Regents of the University of California.279 In Tunkl, the Supreme Court of California invalidated a disclaimer clause in a hospital admission form, stating:

the patient here sought the services which the hospital offered to a selective portion of the public; the patient, as the price of admission and as a result of his inferior bargaining position, accepted a clause in a contract of adhesion waiving the hospital's negligence; the patient thereby subjected himself to control of the hospital and the possible infliction of the negligence which he had thus been compelled to waive. The hospital, under such circumstances, occupied a status different than a mere private party; its contract with the patient affected the public interest. 280

Other than hitting a speed bump with malpractice arbitration cases, 281 the Tunkl approach has proven unassailable in health care provider cases. ${ }^{282}$ However, some interesting fact-intensive issues could arise in regard to a disclaimer incorporated in a website that had both marketing and professional advice content areas, and where the plaintiff's allegations of, say, negligent advice covered data received from both areas. 283

$<$ http://www.ljx.com/internet/ir_ucc.html> (providing hyperlinks to articles that discuss click-wrap issues such as the enforceability of click-wrap agreements).

277 "Click-through" is defined as the process of a visitor clicking on a web advertisement and going to the advertiser's website. See PC Webopaedia: Click-Through (visited Mar. 17, 1999) <http://www.pcwebopaedia.com/TERM/c/click_through.html>.

278 See Hotmail Corp. v. Van\$ Money Pie, 1998 U.S. Dist. LEXIS 10729 (N.D. Cal. 1998). CLICK-WRAP agreements are contracts formed entirely over the Intemet. A party posts terms on its Website pursuant to which it offers to sell goods or services. To buy these goods, the purchaser is required to indicate his assent to be bound by the terms of the offer by his conduct-typically the act of clicking on a button stating "I agree." Once the purchaser indicates his assent to be bound, the contract is formed on the posted terms, and the sale is consummated. No paper record is created nor is the signature of the purchaser required.

OUTSIDE COUNSEL: Click-Wrap Agreement Held Enforceable (visited Mar. 18, 1999) <http://www.ljx.com/internet/0630click.html>.

279383 P.2d 441 (Cal. Sup. Ct. 1963).

280 Id. at 447.

281 See, e.g., Madden v. Kaiser Foundation Hosp., 552 P.2d 1178, 1186 (Cal. 1976) (finding that the Tunkl approach did not apply, because the plaintiff enjoyed the opportunity to select from among several medical plans, some not including arbitration provisions).

282 See Smith v Hosp. Auth. of Walker, Dade and Catoosa Counties, 287 S.E.2d 99 (Ga. Ct. App. 1981) (reversing a trial court summary judgment for defendant hospital, claiming that a blood donor's signed release constituted a bar to the plaintiff's suit); Meiman $v$ Rehabilitation Center, Inc., 444 S.W.2d 78 (Ky. Ct. App. 1969) (reversing a trial court's summary judgment for the defendant rehabilitation center, attempting to rely on an exculpatory contract where defendant's care fell below the relevant standard of care); Cudnik v. William Beaumont Hosp., 525 N.W.2d 891 (Mich. Ct. App. 1994) (invalidating an exculpatory agreement, executed by the plaintiff's decedent before receiving radiation therapy at the defendant hospital); Ash v. New York Univ. Dental Ctr., 164 A.D.2d 366 (N.Y. App. Div. 1990) (invalidating exculpatory agreement required as a precondition to treatment, as against the state's interest in the health and welfare of its citizens and the physician-patient relationship).

283 See Vodopest v. MacGregor, 913 P.2d 779 (Wash. 1996). In Vodopest, the plaintiff participated in a hiking trek in Nepal designed to collect breathing data. See id. at 781. Prior to the experiment, the plaintiff signed an injury release form. See id. The trial court found that the director of the University of Washington Human Subjects Review Committee had rejected the form as invalid, because the federal government did not allow exculpatory language in human subjects experimentation. See id. at 781-82. The Washington Supreme Court concluded that "[t]o the extent the preinjury release . .. attempt[ed] to release the Defendant from negligent conduct during the research on high altitude sickness, it is unenforceable." Id. at 789. 
Of course, disclaimer language is utilized strategically for more than purely exculpatory reasons. At the process level, these include increasing unrepresented consumer information costs and decreasing settlement values of cases. More substantively, defendant statements contained in disclaimers will attempt to nullify defendant representations or warranties and preempt counter-arguments to plaintiff theories based on expectations. Thus, the use of disclaimers can be expected to continue in website construction if for no other reason than that ever-optimistic corporate legal counsel will insist on their inclusion. 284

\section{Site Zoning}

Site zoning or targeting, an issue much discussed in the web pornography debate, 285 concerns the issue of denying access to certain groups or segregating site visitors into subpopulation specific areas.286 Although the pornography debate centers on age verification systems or credit card surrogates, three different types of attempted site zoning seem current on cybermedicine sites.

First and strongly related to the disclaimer issues discussed above, are sites that reject responsibility for off-site content.287 Such a statement does not just disclaim liability; but it also serves as a powerful territorial statement. It may be thought that no such disclaimer is necessary because there could not be any underlying liability exposure. However, such site posting is likely to increase as health care sites become more closely interlinked, and the provider industry becomes more tightly integrated either at an ownership or cross-marketing level.288

The second major zoning attempt is in the demarcation of physician and patient areas. In this context, consider again the Schering-Plough Claritin site discussed in Part V.A.289 Using site personalization and authentication, the site restricts access to a physician-only area using a password or registration number from the Drug Enforcement Agency.290 Contrast it with the Glaxo Wellcome Inc. products page, accessible from its corporate site, 291 which segregates "healthcare professionals only" from "consumers only," but does not then inhibit, say, consumer access to provider-only content. A related approach to site zoning is to differentiate between members and nonmembers, as illustrated by the Oxford Health Plans site that features a guest area, but requires a member personal identification number from participating employers, physicians and patients. ${ }^{292}$

284 It is arguable that the corporate counsel mindset encountered when dealing with web-based information is almost totally informed by the practice of using over-long, excessively elaborate copyright notices when placing any corporate content online.

285 See, e.g., Reno v. A.C.L.U., 521 U.S. 844 (1997) (O'Connor J., concurring and dissenting) (describing efforts to establish zones on the Internet and the constitutional and technological problems that must be overcome to make this effective). See also Lawrence Lessig, The Zones Of Cyberspace, 48 STAN. L. REV. 1403 (1996) (discussing efforts to establish zones for adult material on the Internet).

286 See Lessig, supra note 285, at 1409.

287 See, e.g., Pfizer Extemal Link Page (visited Mar. 17, 1999) <http://www.pfizer.com/kpw/ explore/cgi-bin/xlink/nph-xlink.cgi?link=http://www.healthfinder.gov> (stating "You are now leaving www.pfizer.com/exploringhealth. Links to these outside sites are provided as a resource to the viewer. Pfizer accepts no responsibility for the content of linked sites.").

288 See supra note 18-24 and accompanying text.

289 See supra note 143-48and accompanying text.

290 See Schering-Plough (visited Feb. 7, 1999) <http://www.allergy-relief.com/cgi-bin/ proinfo.cgi>.

291 See Glaxo Wellcome Inc., Product Sites (visited Feb. 7, 1999) <http://www.glaxowellcome.com/prodet.htm> (bypassing site frame).

292 See Oxford Employer Authentication Screen (visited Mar. 17, 1999) <http:/www.oxhp.com/ 
The third identifiable zoning trend on provider websites, again particularly those of pharmaceutical manufacturers, is to zone sites according to real space geographical lines, for example, by reference to the regional or national origin of the web consumer-patient. Thus, many manufacturers' sites proclaim that the information provided is for US residents only. 293 A few sites actually try to direct their traffic 294 and provide country-specific information. ${ }^{295}$

\section{FEDERALLY GRANTED IMMUNITY}

Finally, providing much needed relief from all this liability indeterminacy, many provider sites will seek refuge in 47 U.S.C. $\$ 230$, a piece of federal legislation tucked away in the Communications Decency Act.296 After an early flourish suggesting possible internet service provider (ISP), host or publisher-licensee liability for online content, 297 section $230(\mathrm{c})(1)$ was enacted providing, "[n]o provider or user of an interactive computer service shall be treated as the publisher or speaker of any information provided by another information content provider."298 This has been interpreted to provide blanket immunity from tort liability 299 for ISPs, hosting services and others in the distribution process. ${ }^{300}$ Therefore, sites that

corporate/auth/logemp.html> (requiring an Oxford identification number and a personal identification number to proceed).

293 See Viagra (visited Mar. 17, 1999) <http://www.viagra.com> (stating "The information provided in this site is intended only for residents of the United States. The products discussed herein may have different product labeling in different countries."); Glaxo Wellcome Inc., Product Sites (visited Mar. 21, 1999) <http://www.glaxowellcome.com/prodct.htm> (stating that the information on this site is intended for U.S. health care professionals and consumers only).

294 See Eli Lilly Products (visited Mar. 17, 1999) <http://www.lilly.com/products/usa> (attempting to route the user to particular sites without any authentication or technological zoning, such as by IP address).

295 Compare Eli Lilly Canada-Health Online (visited Mar. 12, 1999) <http://www.lilly.ca/healthon-line/header.html> (providing generalized disease and health information), with Eli Lilly Products (visited Mar. 12, 1999) <http://www.lilly.com/products/usa/index.html> (providing direct access to drug information). The following information is displayed when a user requests specific drug information:

The following information is intended for use only by customers, patients, and health care professionals in the United States. Countries outside the United States may have regulatory requirements or medical practices which are different than those in the United States and may require reference to different or additional information. Therefore, this information may not be appropriate for use outside the United States.

Are you a resident of the United States or one of its territories, or are you a health care professional practicing your profession in the United States or one of its territories?

YES

NQ

Untilled (visited Mar. 18, 1999) <http://www.lilly.com/products/usa>.

296 Title V of the Telecommunications Act of 1996, Pub. L. No. 104-104, 110 Stat. 56 (1996). 47 U.S.C. $\$ 230$ was one of the few provisions to survive Reno v. A.C.L.U., 521 U.S. 844 (1997).

297 See Stratton Oakmont, Inc. v. Prodigy Services Co., 24 Media L. Rep. 1794 (N.Y. Sup. Ct. 1995) (finding Prodigy was a publisher of statements about the plaintiff on its computer bulletin board).

29847 U.S.C.S. $\$ 230$ (c)(1) (1998).

299 Different issues arise in intellectual property cases. See, e.g., Online Copyright Infringement Liability Limitation Act, 17 U.S.C. $\$ \$ 12$ (1998) (limiting liability with regard to intemet service providers (ISPs) to material "published" on their sites with copyright law).

300 See Zeran v. America Online, Inc., 129 F.3d 327 (4th Cir. 1997) (denying the plaintiff's argument that 47 U.S.C. $\S 230$ left intact liability for interactive computer service providers who possess notice of defamatory material posted through their services); Doe v. America Online, Inc., 718 So. 2d 385 (Fla. Ct. App. 1998) (dismissing the plaintiff's complaint that AOL was liable for not taking appropriate action per AOL's Terms of Service and Rules of the Road when an AOL user lured plaintiff's ten-year-old son into having sex, took photographs and offered the photographs in AOL chat 
merely host or sponsor 301 cybermedicine information provided by others should be immune from tort liability. Section 230's correlate, of course, is that the provider of, say, a cybermedicine website that itself authored the content published on the site may be liable for any content-related liability, ${ }^{302}$ assuming that a theory such as those discussed above is adopted. ${ }^{303}$

\section{VIII.CONCLUSION}

This Article has only dealt with a fraction of the issues that exponential growth in cybermedicine will expose. Additional pressing issues already include licensure and other regulatory issues, data integrity issues, not limited to $\mathrm{Y} 2 \mathrm{~K}$ and electronic patient data, and the growing privacy debate as it impacts e-commerce. Unfortunately, extant, real space substantive rules dealing with information flow and content liability are poorly realized, making mapping difficult. And, of course, any general cyberspace law itself is immature. Most liability-oriented cases have been poorly, generally vaguely, pleaded or have been primarily concerned with process issues such as jurisdiction ${ }^{304}$ or the interpretation of new statutory issues.

rooms).

301 of course, this should not be read to suggest that a site sponsor would in any event be liable. See, e.g., Archer v. Outboard Marine Corp., 908 S.W.2d 701 (Mo. Ct. App. 1995). The surviving victim of a boating accident and widow and mother of other victim brought an action for damages against a fishing toumament sponsor after a boating accident with a toumament competitor. See id. at 702 . The circuit court granted summary judgment for the toumament sponsor, and the plaintiffs appealed. See id. The court of appeals held that: (1) sponsorship did not cause the crash, and (2) its sponsor did not exercise sufficient control over a toumament to render it liable. See id. at 703-04. Cf. Rudolph v. Arizona B.A.S.S. Federation, 898 P.2d 1000 (Ariz. App. 1995) (finding defendant owed the plaintiff a duty to assure that all participants in a timed competition operated their boats safely and in a reasonable manner without endangering the peace and safety of other persons in and about the lake where the competition was held).

302 Although somewhat unclear in the opinion, this seems to have been the plaintiff's failing argument in Blumenthal v. Drudge, 992 F. Supp. 44 (D.D.C. 1998). "The term "information content provider' means any person or entity that is responsible, in whole or in part, for the creation or development of information provided through the Internet or any other interactive computer service." 47 U.S.C. $\$ 230(e)(3)$.

303 See supra note 205-261 and accompanying text.

304 See, e.g., GTE New Media Servs. v. Ameritech Corp., 1998 U.S. Dist. LEXIS 15413 (D.D.C. 1998) (denying the defendant's Federal Rules of Civil Procedure 12(b)(2) motion to dismiss for lack of personal jurisdiction, because the continuous contact the defendant's interactive websites had with the forum district demonstrated that the defendants purposefully established minimum contacts, invoking the benefits and privileges of conducting activities in the forum district); Panavision Int'l, L.P. v. Toeppen, 141 F.3d 1316 (9th Cir. 1998) (affirming summary judgment for the plaintiff Panavision, because the defendant's actions were aimed at the plaintiff in the forum state, and caused the plaintiff to suffer injury there); Cybersell, Inc. v. Cybersell, Inc., 130 F.3d 414, 415 (9th Cir. 1997) (denying an Arizona plaintiff's argument that a Florida defendant was subject to personal jurisdiction because cyberspace is without borders, and a website that advertises a product or service is necessarily intended for use on a world-wide basis); No-Mayo v. Memminger, 1998 U.S. Dist. LEXIS 13154 (N.D. Cal. 1998) (granting summary judgment to the defendants, finding that defendants did not purposefully avail themselves of the privilege of doing business in the forum state of Califomia, and that the due process requirements for personal jurisdiction were not met); Conseco, Inc. v. Hickerson, 698 N.E.2d 816 (Ind. App. Ct. 1998) (holding that the defendant's discussion of the plaintiff organization in his website, without any other contacts, was not a minimum contact sufficient to allow the forum state to exercise personal jurisdiction over him); Minnesota v. Granite Gate Resorts, Inc., 568 N.W.2d 715 (Minn. Ct. App. 1997), affd 576 N.W.2d 747 (Minn. 1998) (finding that the defendants were subject to personal jurisdiction in Minnesota by advertising a forthcoming online gambling service on the Intemet and by developing from the Internet a mailing list that includes one or more Minnesota residents, thereby not offending the traditional notions of fair play and substantial justice). 
Although telemedicine has already attracted the attention of legal scholars, 305 this is nothing compared with the likely development of cybermedicine and cybermalpractice. The expansion of health care providers into virtual space will fundamentally change their methods of operation, their relationships with peer providers and patients and the types of interaction in which they indulge. Provider choices of business models, combined with the novelty of many of the malpracticelike claims that will result, and will wreak a sea change in health care provider liability law, a changing risk allocation that likely will also reverberate in real space.

305 In the Lexis $($-Nexis $($ Law Review file, there were 82 hits as of January 16, 1999. On the same date there were no hits for "cybermedicine." In contrast, there have been some news items discussing cybermedicine. See, e.g., 'Cybermedicine' causes concern, CINCINNATI ENQUIRER, Nov. 15, 1998, at E7; Jennings, supra note 182, at 1A.; Docs Explore Whether Online Medicine Is Good Medicine, supra note 27. 